\title{
Reliability of reinforced concrete beams designed in accordance with Brazilian code NBR-6118:2014
}

\section{Confiabilidade de vigas de concreto armado dimensionadas de acordo com a NBR-6118:2014}
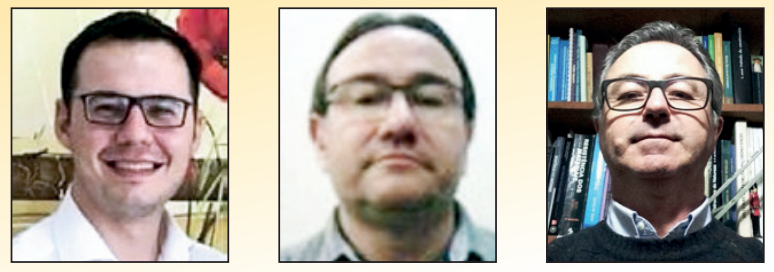

M. SCHERER a
mailson scherer@hotmail.com
https://orcid.org/0000-0001-7544-0623
$\begin{array}{r}\text { I. B. MORSCH a } \\ \text { morsch@ufrgs.br }\end{array}$
$\begin{array}{r}\text { https://orcid.org/0000-0002-2473-3474 } \\ \text { M. V. REAL b } \\ \text { hauroreal@furg.br } \\ \text { https://orcid.org/0000-0003-4916-9133 }\end{array}$

\section{Abstract}

This paper aims to evaluate the reliability indexes of reinforced concrete beams designed in accordance with brazilian code NBR-6118:2014 in relation to the ultimate limit state of flexure. The main statistics of the resistance model are obtained through Monte Carlo simulation using ANSYS software and its probabilistic design tool. The reliability indexes are evaluated by FORM, being performed a parametric study in order to assess the influence of the main design variables on the safety level reached. It can be noticed that the reliability indexes are shown unsatisfactory in the combinations which the live loads are predominant.

Keywords: structural reliability, reinforced concrete, finite element method, Monte Carlo Method, FORM.

\section{Resumo}

O presente trabalho busca avaliar o índice de confiabilidade atingido pelas vigas de concreto armado dimensionadas de acordo com a norma brasileira NBR-6118:2014 em relação ao estado limite último de flexão. As principais estatísticas das resistências são obtidas por simulações de Monte Carlo utilizando o software ANSYS e a ferramenta probabilistic design. Os índices de confiabilidade são calculados pelo FORM, sendo realizado um estudo paramétrico para avaliar a influência das principais variáveis de projeto nos níveis de segurança atingidos. É observado que os índices de confiabilidade se mostram insatisfatórios para combinações de carga nas quais as cargas acidentais são predominantes.

Palavras-chave: confiabilidade estrutural, concreto armado, método dos elementos finitos, Método de Monte Carlo, FORM. 


\section{Introduction}

Concrete structures projects have come to experience a series of advances which range from the materials used to the calculation methods practiced by engineers and designers. When it comes to safety in reinforced concrete structures, the NBR-6118: 2014 code uses a semi-probabilistic method to obtain a safety level in design, increasing loads and reducing resistances through partial weighting coefficients. These coefficients are applied on characteristic values of resistances, obtained from tests, and on estimated loads, while the geometry and dimension of the structures correspond to the nominal values specified in design. The current method replaces the obsolete method of allowable stresses, allowing the design of more economical and safe structures [1].

The prediction of the response of reinforced concrete beams, either under service loads or under the failure load, reveals a series of complexities, from those related to the behavior of the materials used, as well as uncertainties in the considerations adopted in the design step. According to Real [1], these uncertainties hang on the calculation models, the properties of the used materials, on the maximum loads acting throughout the life cycle of the structure and even on the geometry of the structure, which can suffer deviations during the construction, preventing the determination of the final dimensions with accuracy. It can be noted, therefore, that the most of the variables involved in the design step correspond to a set of random variables, which have a certain probabilistic distribution, presenting mean values and a certain dispersion value. This results in a structure whose response, under certain loading condition, is also revealed in a random way.

A rational way of considering uncertainty is to treat the problem in a probabilistic format. In this sense, there are some studies that have already been carried out and are directed to the study and evaluation of the safety level by the brazilian code NBR-6118 in its various reviews. A probabilistic study on beams and columns was developed by Real [1], evaluating the criteria established by NBR-6118:1980. A study on reinforced concrete beams was developed by Santos et al. [12] in relation to the revision of NBR-6118:2007. With regard to the last review, NBR-6118:2014, it can be mentioned the works developed by Minasi [16], focused on the reliability of reinforced concrete beams in port structures; by Barbosa [5], directed to the probabilistic analysis of reinforced concrete columns; and by Silva [11], in the evaluation of the reliability of the slab-column link under punching. As a way to contribute to and follow up the study of the safety level reached by the national design codes, the main objective of this work is to determine the reliability index in projects of reinforced concrete beams in relation to the ultimate limit state of flexure, dimensioned in accordance with the requirements and design criteria of NBR-6118: 2014. The finite element method is used for the numerical representation of the designed beams, being this model compared and validated through experimental results. The probabilistic study, in turn, is done through the Monte Carlo Method and FORM.

\section{Design of reinforced concrete beams according to NBR-6118:2014}

In general, in addition to addressing aspects related to structural safety, the design step of reinforced concrete structures should in- clude checks on serviceability performance and durability over the life of the structure. In this context, it is customary to define the ultimate limit state, which are related to the collapse or exhaustion of the carrying capacity of the structure, and the serviceability limit states, which refer to the conditions in which the use of the structure in terms of comfort and durability.

\subsection{Load combination}

The load combination should consider all loads of a non-negligible probability of acting simultaneously, in order to determine the most unfavorable effects for the structure, both in relation to the serviceability limit states and the ultimate limit states [4]. Thus, it is necessary to know the main phases of the life cycle of a structure, making it possible to determine unfavorable conditions and ensure an adequate margin of safety by adopting partial coefficients for resistances and actions.

With respect to the load combination in the verification to the ultimate limit state, considering last normal combinations, these are obtained, according to NBR-6118: 2014, through expression (2.1).

$\mathrm{F}_{\mathrm{d}, \mathrm{ult}}=\gamma_{\mathrm{g}} \mathrm{F}_{\mathrm{gk}}+\gamma_{\mathrm{q}}\left(\mathrm{F}_{\mathrm{q} 1 \mathrm{k}}+\sum \Psi_{0 \mathrm{j}} \mathrm{F}_{\mathrm{q}, \mathrm{k}}\right)$

Being $F_{d, u l t}$ the design value for the last combination of normal requests; $F_{g k}$ the characteristic value of the dead load; $F_{q 1 k}$ the characteristic value of the main live load; $F_{\mathrm{q} j \mathrm{k}}$ the characteristic value of the other live loads; $\gamma_{g}$ and $\gamma_{q}$ the partial coefficients for dead and live loads, respectively; $\psi_{0 \mathrm{j}}$ the reducing coefficient in the load combination.

For the most usual cases, the values of the partial coefficients indicated by code result in $\gamma_{\mathrm{g}}=\gamma_{\mathrm{q}}=1,4$, and the reducing coefficient for the other live loads, other than the main one, is adopted $\psi_{0 \mathrm{j}}=0,50$. Thus, in relation to the ultimate limit state, the design value of the load is given by (2.2).

$\mathrm{F}_{\mathrm{d}, \mathrm{ult}}=1,4\left(\mathrm{~F}_{\mathrm{gk}}+\mathrm{F}_{\mathrm{q} 1 \mathrm{k}}\right)+1,4 \sum 0,50 \mathrm{~F}_{\mathrm{qj}, \mathrm{k}}$

In relation to serviceability limit states, the load combination is done considering the duration of the loads on the structure. For loads that will act on the structure during a great part of its life cycle, these have their values taken as quasi-permanent, being the combination given by the expression (2.3).

$\mathrm{F}_{\mathrm{d}, \mathrm{qp}}=\sum \mathrm{F}_{\mathrm{gi}, \mathrm{k}}+\sum \Psi_{2 \mathrm{j}} \mathrm{F}_{\mathrm{qj}, \mathrm{k}}$

Being $F_{d, q p}$ the design value for the quasi-permanent combination and $\psi_{2 j}$ the reducing coefficient in the load combination. The quasipermanent combination, according to NBR-6118: 2014, should be used to check displacements. Considering live loads from residential buildings, the reduction factor is taken as $\psi_{2 \mathrm{j}}=0,30$. With this, the equation (2.3) can be rewritten by (2.4).

$\mathrm{F}_{\mathrm{d}, \mathrm{qp}}=\sum \mathrm{F}_{\mathrm{gi}, \mathrm{k}}+0,30 \mathrm{~F}_{\mathrm{qj}, \mathrm{k}}$

In the case of actions that are repeated several times throughout the life cycle of the structure, the main live load is taken with its frequent value, while the others assume their quasi-permanent values. In this condition, the combination is given by (2.5).

$\mathrm{F}_{\mathrm{d}, \mathrm{f}}=\sum \mathrm{F}_{\mathrm{gi,k}}+\Psi_{1} \mathrm{~F}_{\mathrm{q} 1 \mathrm{k}}+\sum \Psi_{2 \mathrm{j}} \mathrm{F}_{\mathrm{qj}, \mathrm{k}}$

Being $F_{d, f}$ the design value for the frequent combination. The verification of cracking is performed using equation (2.5). For life 


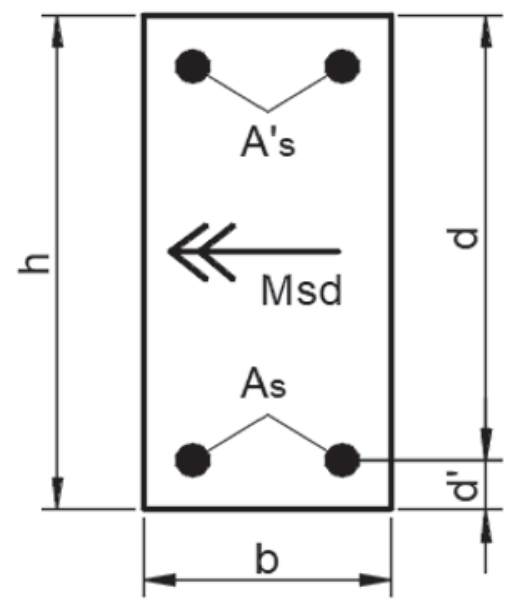

Figure 2.1

Generic rectangular cross-section under flexure

loads from residential buildings, it is adopted $\psi_{1}=0,40$, rewriting (2.5) as (2.6).

$\mathrm{F}_{\mathrm{d}, \mathrm{f}}=\sum \mathrm{F}_{\mathrm{gi}, \mathrm{k}}+0,40 \mathrm{~F}_{\mathrm{q} 1 \mathrm{k}}$

\subsection{Flexural design}

The design step of reinforced concrete beams consists, for a given geometry and loading condition established in a design stage, in determining the quantity and arrangement of reinforcement to reach the safety condition $M_{R d} \geq M_{S d}$, being $M_{R d}$ and $M_{S d}$ the design values of the resistant and external moment, respectively.

In this work it's considered a rectangular cross-section, represented generically in Figure 2.1. As basic assumptions of flexural design, sections are considered to remain planes after deformation; a perfect adhesion between the reinforcement and the concrete surrounding it is admissible; the contribution of tensioned concrete is completely neglected [4]. Considering the case of beams under simple flexure, the failure is characterized by the crushing of the concrete or the yielding of the reinforcement. Thus, it is assumed that the equilib-

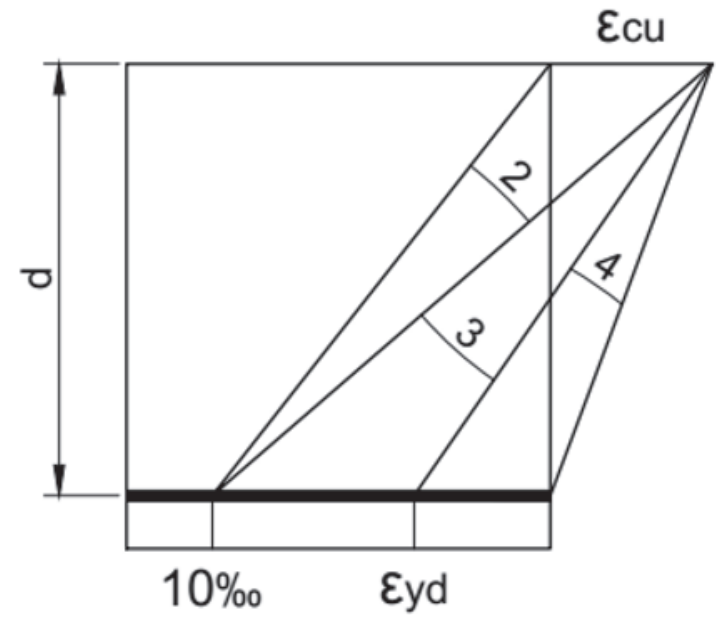

Figure 2.2

Considered domains for simple flexure failure

rium of a cross-section under these conditions will occur in domains 2, 3 (ductile rupture condition), shown in Figure 2.2.

The occurrence of the above domains is characterized by the position of the neutral axis in the cross-section. In order to guarantee ductility to the beams, NBR-6118: 2014 establishes the limits of the relative position of the neutral axis $\xi=x / d$ according to the concrete class, as a function of the characteristic strength $\left(f_{c k}\right)$, according to (2.7).

$$
\xi_{\text {lim }} \leq 0,45 \quad \mathrm{f}_{\mathrm{ck}} \leq 50 \mathrm{MPa}
$$$$
\xi_{\text {lim }} \leq 0,35 \quad 50 \mathrm{MPa}<\mathrm{f}_{\mathrm{ck}} \leq 90 \mathrm{MPa}
$$

Although the concrete in compression presents non-linear behavior, it is possible to consider a rectangular block of stresses [4], represented in Figure 2.3, acting together with the tensioned reinforcement and thus balancing the bending moment.

The rectangular block of the concrete in compression can be considered up to a position $y=\lambda x$, being $\lambda$ a constant adopted as a function of the concrete class, according to (2.8).

$$
\begin{array}{ll}
\lambda=0,8 & \mathrm{f}_{\mathrm{ck}} \leq 50 \mathrm{Mpa} \\
\lambda=0,8-\left(\frac{\mathrm{f}_{\mathrm{ck}}-50}{400}\right) & \mathrm{f}_{\mathrm{ck}}>50 \mathrm{MPa}
\end{array}
$$

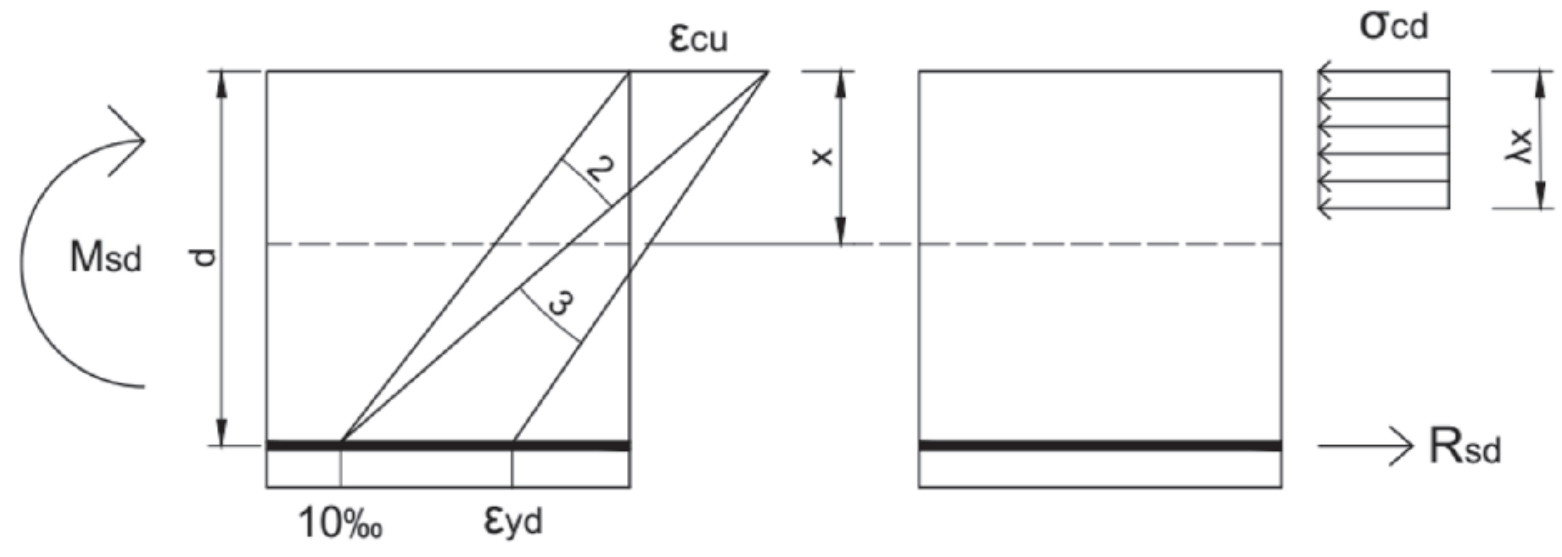

Figure 2.3

Equilibrium of internal forces to the external moment 
The equilibrium of the section shown in Figure 2.3 results in a quadratic equation with respect to the position of the neutral axis $x$, which only concerns the value contained in the cross-section, given by expression (2.9).

$\mathrm{x}=\frac{\mathrm{d}}{\lambda}\left(1-\sqrt{1-2 \frac{\mathrm{M}_{\mathrm{sd}}}{\mathrm{bd}^{2} \sigma_{\mathrm{cd}}}}\right)$

$\sigma_{\mathrm{cd}}=\frac{\alpha_{\mathrm{c}} \mathrm{f}_{\mathrm{ck}}}{\gamma_{\mathrm{c}}}$

Being $\sigma_{c d}$ the design value of the compressive strength of the concrete; $\alpha_{c}$ is a parameter of reduction of the concrete resistance in the compression, as a function of the concrete class; $\gamma_{c}$ the weighting coefficient of the concrete strength.

It can be introduced, through (2.11), the dimensionless variable $\mu$, which represents the reduced bending moment, being only function of the pre-established geometry and the design values of the resistance and loads.

$\mu=\frac{\mathrm{M}_{\mathrm{sd}}}{\mathrm{bd}^{2} \sigma_{\mathrm{cd}}}$

The verification of the ductility condition is obtained by comparing the reduced bending moment with its corresponding limit value obtained by expression (2.12)

$\mu_{\lim }=\lambda \xi_{\lim }\left(1-0,5 \lambda \xi_{\lim }\right)$

Once it is ensured that $\mu \leq \mu_{\text {lim }}$, confirming the position of the neutral axis in domains 2 or 3 , the solution consists in a simple reinforcement arrangement, without compressive reinforcement. In this situation, the reinforcement area $\mathrm{A}_{\mathrm{s}}$ is obtained through (2.13) and (2.14).

$\xi=\frac{1}{\lambda}(1-\sqrt{1-2 \mu})$

$\mathrm{A}_{\mathrm{s}}=\lambda \xi \mathrm{bd} \frac{\sigma_{\mathrm{cd}}}{\mathrm{f}_{\mathrm{yd}}}$

Being $f_{y d}=f_{y k} / \gamma_{s}$ the design yielding stress of reinforcement; $f_{y k}$ the characteristic value of the yielding stress; $\gamma_{s}$ the coefficient of resistance of the steel.

For situations where $\mu>\mu_{\text {lim }}$, the ductile failure condition in domain 2 or 3 without change in geometry and material resistance is obtained by adopting a compressive reinforcement $\left(A_{s}{ }^{\prime}\right)$. Therefore, the problem is indeterminate, since the three unknowns $A_{s}, A_{s}$ and $\xi$ must be obtained by two equilibrium equations in the cross-section. An alternative is to fix $\xi=\xi_{\text {im }}$, obtaining the tensioned and compressive reinforcement areas by equilibrium [3]. The strain and stress in the compressive reinforcement, $\xi_{\mathrm{s}}{ }_{\mathrm{s}}$ and $\sigma_{\mathrm{sd}}{ }^{\prime}$, respectively, are given by expressions (2.15) and (2.16).

$\varepsilon_{\mathrm{s}}^{\prime}=\varepsilon_{\mathrm{u}}\left(\frac{\xi_{\lim }-\mathrm{d} / \mathrm{d}^{\prime}}{\xi_{\lim }}\right)$

$\sigma_{\text {sd }}{ }^{\prime}=E_{\mathrm{s}} \varepsilon_{\mathrm{s}}$

Being $E_{s}$ the young's modulus of the reinforcement. In this condition, the tensioned and compressive reinforcement area, $A_{s}$ and $A_{s}{ }^{\prime}$, are obtained by expressions (2.17) and (2.18), respectively.

$A_{s}=\left(\lambda \xi_{\lim }+\frac{\mu-\mu_{\lim }}{1-d / d^{\prime}}\right) b d \frac{\sigma_{c d}}{f_{y d}}$
$\mathrm{A}_{\mathrm{s}}^{\prime}=\left(\frac{\mu-\mu_{\mathrm{lim}}}{1-\mathrm{d} / \mathrm{d}^{\prime}}\right) \mathrm{bd} \frac{\sigma_{\mathrm{cd}}}{\sigma_{\mathrm{sd}}{ }^{\prime}}$

The tensioned reinforcement area must also comply with a minimum value in order to avoid a brittle failure in the transition from Stage I to Stage II. The minimum tensioned reinforcement area is obtained by designing the minimum bending moment [4], given by (2.19), and the minimum geometric rate of $0.15 \%$ must be respected.

$\mathrm{M}_{\mathrm{sd}, \min }=0,8 \mathrm{~W}_{0} \mathrm{f}_{\mathrm{ctk}, \text { sup }}$

Being $W_{0}$ the section resistant module, relative to the more tensioned fiber; and $\mathrm{f}_{\mathrm{ctk} \text {,sup }}$ the upper bound of the characteristic tensile strength of the concrete.

\subsection{Verification of serviceability limit states}

In addition to the design of the longitudinal reinforcement to flexure, in order to guarantee an adequate safety level in relation to the failure, it must also be ensured that the structure performs well under normal conditions of use, in order to guarantee comfort and durability [3]. For reinforced concrete beams, the excessive displacements limit states and the crack opening limit state are usually checked. Although these two limit states are related, both are checked in isolation according to the procedure presented in NBR-6118:2014.

\subsubsection{Verification of excessive displacements}

Under service loads, the concrete starts the cracking process in the most loaded sections, reducing in a significant way the stiffness of the structure. In this case, the obtaining of the immediate displacements presumes the consideration of an equivalent stiffness considering the state of cracking of the beam. According to NBR 6118: 2014 [4], the equivalent stiffness $(E I)_{\text {eq }}$ is obtained by expression (2.20).

$(\mathrm{EI})_{\mathrm{eq}}=\mathrm{E}_{\mathrm{cs}}\left\{\left(\frac{\mathrm{M}_{\mathrm{r}}}{\mathrm{M}_{\mathrm{a}}}\right)^{3} \mathrm{I}_{\mathrm{c}}+\left[1-\left(\frac{\mathrm{M}_{\mathrm{r}}}{\mathrm{M}_{\mathrm{a}}}\right)^{3}\right] \mathrm{I}_{\mathrm{II}}\right\} \leq \mathrm{E}_{\mathrm{cs}} \mathrm{I}_{\mathrm{c}}$

Being $E_{c s}$ the secant modulus of elasticity of the concrete; $M_{r}$ the cross-sectional cracking moment; $M_{a}$ the maximum moment in the span for the considered load combination; $I_{c}$ and $I_{\|}$the moments of inertia of the concrete section and the section in Stage II, respectively. Due to the rheological behavior of the concrete, an additional portion of displacement due to long time effects due to creep and shrinkage must be considered. This additional portion is obtained by multiplying the immediate displacement by a factor $\alpha_{\mathrm{f}}$, presented in (2.21).

$\alpha_{\mathrm{f}}=\frac{\Delta \xi}{1+50 \rho^{\prime}}$

In the above expression, $\rho^{\prime}$ means the longitudinal compressive reinforcement ratio. The factor $\Delta \xi$, depends on the time interval between the date on which the final displacements is measured and the date corresponding to the loading of the structure. In this work, a value of $\Delta \xi=1,32$ is considered. The final displacement $\delta_{f}$ is obtained by the expression (2.22). In the case of simply supported beams, the limit value of $\delta_{\text {lim }}=\mathrm{L} / 250$ must be respected. 
$\delta_{\mathrm{f}}=\delta_{0}\left(1+\alpha_{\mathrm{f}}\right)$

Being $\delta_{0}$ the short-time displacement calculated with the equivalent stiffness $(E \mathrm{I})_{\mathrm{eq}}$.

\subsubsection{Verification of crack opening}

In the sense of the preservation and integrity of concrete structures, the control of cracking is aimed at ensuring the inhibition of processes that promote the deterioration of the reinforcement, such as corrosion [3]. According to NBR-6118: 2014 [4], the characteristic crack opening $w_{k}$ for each wrap region should be considered as the lowest obtained by expressions (2.23) and (2.24).

$\mathrm{w}_{\mathrm{k}}=\frac{\phi_{\mathrm{i}}}{12,5 \eta_{\mathrm{i}}} \frac{\sigma_{\mathrm{si}}}{\mathrm{E}_{\mathrm{si}}} \frac{3 \sigma_{\mathrm{si}}}{\mathrm{f}_{\mathrm{ctm}}}$

$\mathrm{w}_{\mathrm{k}}=\frac{\phi_{\mathrm{i}}}{12,5 \eta_{\mathrm{i}}} \frac{\sigma_{\mathrm{si}}}{\mathrm{E}_{\mathrm{si}}}\left(\frac{4}{\rho_{\mathrm{ri}}}+45\right)$

Being $\varphi_{i}$ the diameter of the bar that protects the region of involvement; $\sigma_{\mathrm{si}}$ the tensile stress in the reinforcement bar considered; $\eta_{i}$ the coefficient of conformation of the reinforcement bar; $E_{s i}$ the young's modulus of the reinforcement bar considered; $\rho_{\mathrm{ri}}$ the reinforcement ratio of the region considered; $f_{c t m}$ the average tensile strength of the concrete.

The crack opening value must be observed according to the environmental class in which the structure is inserted, according to NBR-6118: 2014 [4]. In the present work, a class of environmental aggression II was considered, leading to a maximum value of crack opening $w_{k} \leq 0,30 \mathrm{~mm}$.

\section{Analysis of reinforced concrete beams by the finite element method}

The reliability study assumes the existence of a model, either anaIytical or numerical, that allows to adequately represent the behavior of the structure under study, especially with regard to the ultimate load values. In this work, the finite element method was used for the analysis of reinforced concrete beams. The analyzes were performed through the software ANSYS 17.2, in its academic

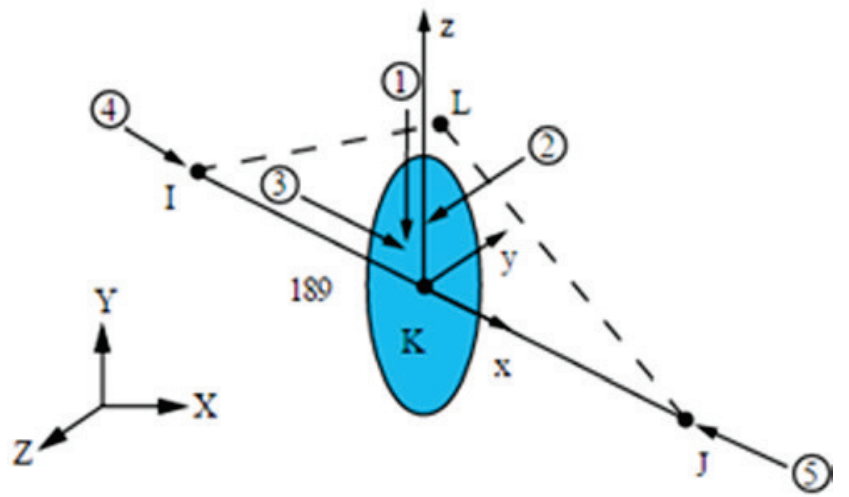

Figure 3.1

Element Beam189 for concrete representation (ANSYS, [6]) version, associating the usermat external subroutines for the representation of the constitutive law of the materials. These subroutines are programmed in Fortran 77 language, using a code update initially developed by Barbosa [5] for the probabilistic study of columns. The finite elements adopted and the mechanical models of the materials are presented in more detail below.

\subsection{Finite elements used}

\subsubsection{Finite element for concrete}

The beam189 element can be employed in the analysis of slender bar structures, such as thin or moderately slender columns and beams. Being based on the theory of beams of Timoshenko, which considers shear deformations, the sections remain plane after the deformation [6]. It is a unidimensional element contained in threedimensional space, which has three nodes along its length (quadratic formulation), there being six degrees of freedom per node (3 translations and 3 rotations around the local axes $x, y$ and $z$ ). Figure 3.1 shows the geometry, nodes, and local coordinate system for the element in question.

The beam189 has two gauss points along its length and four gauss points for each cell used to represent the cross-section. Figure 3.2 shows the gauss points associated with the beam189 element along the length and in relation to the cross section.

A notable advantage of using this element is its compatibility with the reinf264 element, which is adopted as an embedded reinforcement model and associated with the smeared crack model for concrete.
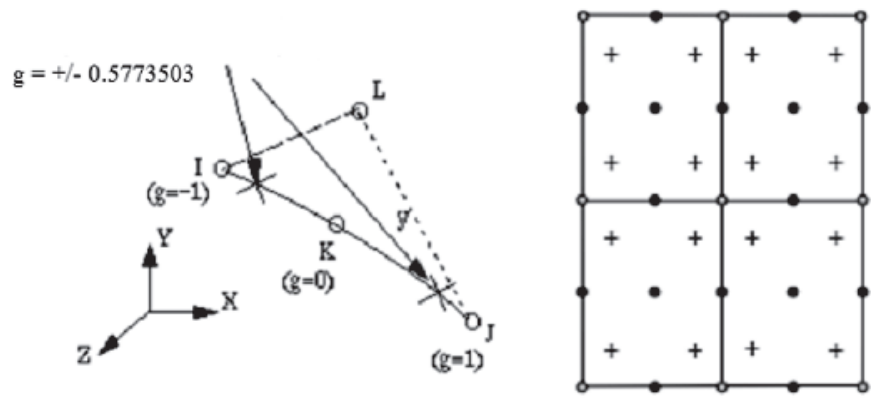

Figure 3.2

Gauss points associated with the beam189 element (adapted from ANSYS, [6])
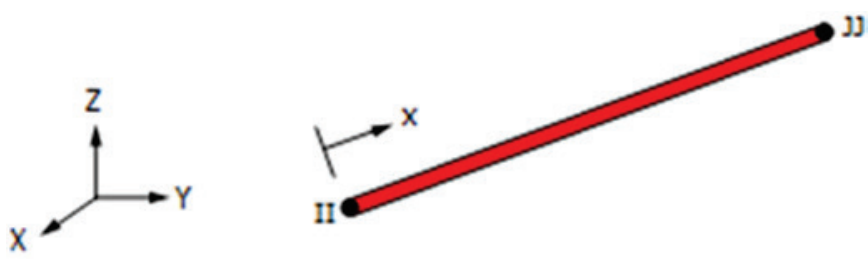

Figure 3.3

Element Reinf264 for reinforcement representation (ANSYS, [6]) 


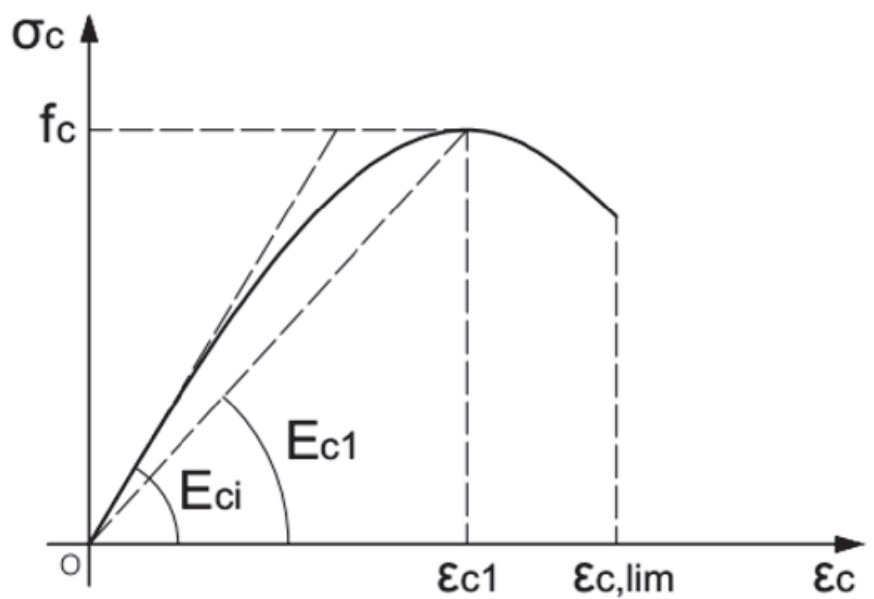

Figure 3.4

Stress-strain relation for concrete in uniaxial compression (adopted from fib 2010, [14])

\subsubsection{Finite element for reinforcement}

The reinforcements were represented by the reinf264 element, shown in Figure 3.3. It is an element which assumes the existence of a base element, such as beam 189 described above. The nodal coordinates, degrees of freedom and connectivity of the reinf264 element are identical to that of the base element.

Its formulation allows the representation of fibers of reinforcement acting in arbitrary directions and resisting exclusively axial forces. These fibers are associated to the base element assuming complete adherence with the same, being inserted through relative positions in the cross section [6].

\subsection{Mechanical model of materials}

In this item are presented the mechanical models used in numerical modeling. The main properties that define the mechanical model of concrete and reinforcement are obtained through simulation, according to the probability distribution attributed to them. These aspects related to the random variables are conveniently addressed in item 6.2.

\subsubsection{Concrete}

Due to its composition, the behavior of concrete tends to be complex, presenting also completely different responses when tensioned or compressed [7]. In order to carry out the analyzes, the constitutive relations and prescriptions presented in the model code fib 2010 [14] were adopted, being applicable for concretes with characteristic strenght of up to $120 \mathrm{MPa}$. We also used criteria and adaptations suggested by researchers and technical literature on the subject.

When compressed, the concrete tends to present non-linearities still on low values of stresses, being its constitutive model in uniaxial compression represented by the stress-strain diagram presented in Figure 3.4.
The stress peak corresponds to the compressive strength $f_{c}$, proceeding by a post-peak stretch with softening, occurring the rupture upon reaching the ultimate strain in compression. The expressions and parameters given in (3.1) characterize the curve represented in Figure 3.4.

$\sigma_{\mathrm{c}}=-\mathrm{f}_{\mathrm{c}}\left(\frac{\mathrm{k} \eta-\eta^{2}}{1+(\mathrm{k}-2) \eta}\right) \quad\left|\varepsilon_{\mathrm{c}}\right|<\left|\varepsilon_{\mathrm{c}, \mathrm{lim}}\right|$

$\eta=\frac{\varepsilon_{\mathrm{c}}}{\varepsilon_{\mathrm{c} 1}} \quad \mathrm{k}=\frac{\mathrm{E}_{\mathrm{ci}}}{\mathrm{E}_{\mathrm{c} 1}}$

Concrete, since it has a tensile strength that is much lower than its compressive strength, presents cracks even at a low load level. According to Hinton [7], the representation of the tensioned concrete comprises the introduction of a cracking criterion and a softening law. In this work, non-cracked foncrete, whose tensile stresses do not exceed the resistance $\mathrm{I}_{\mathrm{ct}}$, is represented as a linear-elastic model [15], the constitutive relation given by (3.2).

$\sigma_{\mathrm{t}}=\mathrm{E}_{\mathrm{ci}} \varepsilon_{\mathrm{t}} \quad \sigma_{\mathrm{t}} \leq \mathrm{f}_{\mathrm{ct}}$

After cracking, the concrete between cracks continues to collaborate in the resistance up to a given level of strain. This behavior, called tension-stiffening, is modeled by a descending branch in the stress-strain diagram, which represents a gradual reduction in stiffness as a function of the level of crack opening, as shown in Figure 3.5.

In this work, the expression used by Martinelli [15] was used to represent the stress-strain diagram of the cracked concrete, given by (3.3), using values of $\alpha_{\mathrm{t}}$ and $\varepsilon_{\mathrm{tu}}$ equal to 0.6 and 0.001 , respectively.

$\sigma_{\mathrm{ct}}=\alpha_{\mathrm{t}} \mathrm{f}_{\mathrm{ct}}\left(1,0-\frac{\varepsilon_{\mathrm{t}}}{\varepsilon_{\mathrm{tu}}}\right)$

\subsubsection{Reinforcement}

For the representation of the reinforcement, a perfect elastoplastic model was used, as shown in Figure 3.6. The material has the same behavior under tension and compression, presenting an young's modulus $E_{s}$ until it reaches the yield stress $f_{y^{\prime}}$ from which it presents a null tangent modulus.

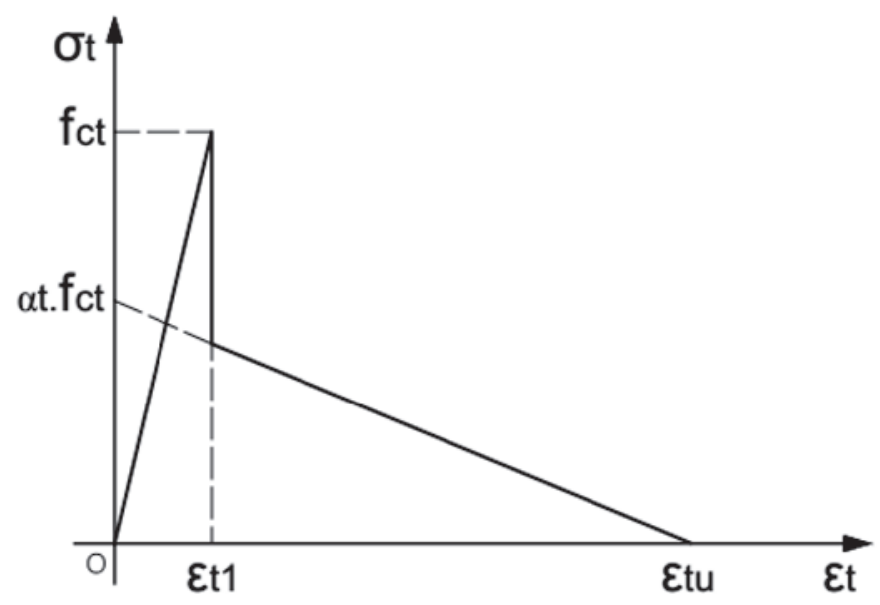

Figure 3.5

Stress-atrain relation for concrete in uniaxial tension (adopted from Martinelli, [15]) 


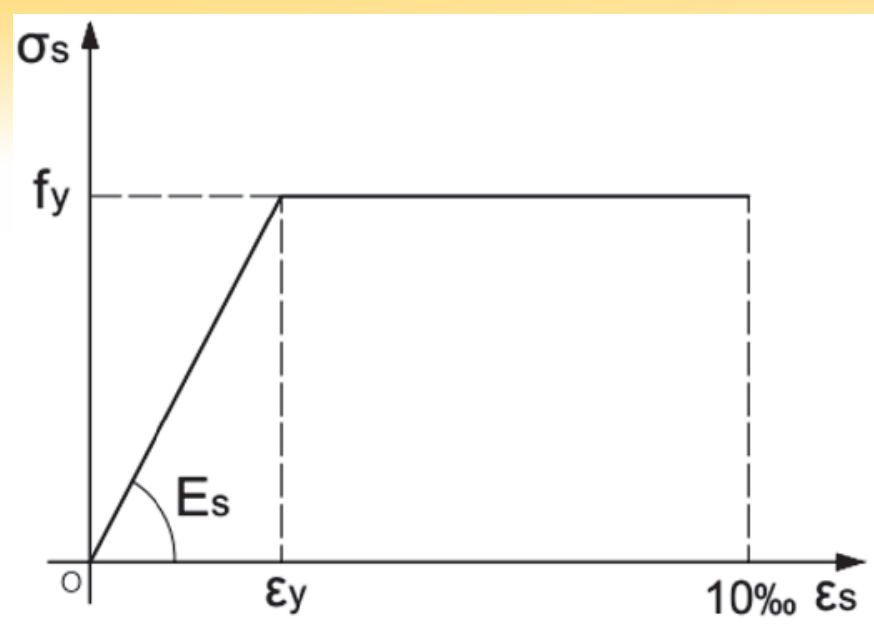

Figure 3.6

Stress-strain relation for reinforcement

\section{Numerical model validation}

In order to verify the numerical model's ability to obtain the ultimate load of reinforced concrete beams, a set of nine beams tested by Schegg and Decanini [8] are modeled numerically. The beams were subjected to concentrated loads, as shown in Figure 4.1, being loaded gradually until failure.

The beams were divided into three different sets, differentiated in relation to the longitudinal reinforcement ratio. Table 4.1 shows the geometric parameters and strengths measured after the construction of the beams.

The mesh used for discretization of the model is presented in Figure 4.2. Twelve elements were used along the length of the beam, while the cross section was divided into four cells along the base and six cells along the height.

Figures $4.3,4.4$ and 4.5 show the load-displacement diagrams for the first beam of each series tested. It can be verified that the

\section{Table 4.1}

Properties of the beams tested by Schegg and Decanini [8]

\begin{tabular}{|c|c|c|c|c|c|c|c|}
\hline Beam & $\begin{array}{c}b \\
(\mathrm{~cm})\end{array}$ & $\begin{array}{c}\mathrm{h} \\
(\mathrm{cm})\end{array}$ & $\begin{array}{c}d \\
(\mathrm{~cm})\end{array}$ & $\begin{array}{c}f_{\mathrm{cm}} \\
\left(\mathrm{kN} / \mathrm{cm}^{2}\right)\end{array}$ & $\begin{array}{c}f_{y} \\
\left(k N / \mathrm{cm}^{2}\right)\end{array}$ & $\begin{array}{c}A_{\mathrm{s}} \\
\left(\mathrm{cm}^{2}\right)\end{array}$ & $\begin{array}{c}A_{s_{s}} \\
\left(\mathrm{~cm}^{2}\right)\end{array}$ \\
\hline RC-075-1 & 15.3 & 24.6 & 22.1 & 3.11 & 54.9 & \multirow{3}{*}{$\begin{array}{c}2,35 \\
(3 \phi 10 \mathrm{~mm})\end{array}$} & \multirow{9}{*}{$1,00(2 \phi 8 \mathrm{~mm})$} \\
\hline RC-075-2 & 14.9 & 24.7 & 21.9 & 2.82 & 53.8 & & \\
\hline RC-075-3 & 14.6 & 24.8 & 22.1 & 2.96 & 54.8 & & \\
\hline RC-100-1 & 15.0 & 23.9 & 21.7 & 3.22 & 43.8 & \multirow{3}{*}{$\begin{array}{c}3,39 \\
(3 \phi 12 \mathrm{~mm})\end{array}$} & \\
\hline RC-100-2 & 14.6 & 23.9 & 21.7 & 3.40 & 42.7 & & \\
\hline RC-100-3 & 15.0 & 23.9 & 21.7 & 2.74 & 42.5 & & \\
\hline RC-200-1 & 15.0 & 24.0 & 21.2 & 2.64 & 48.4 & \multirow{3}{*}{$\begin{array}{c}6,28 \\
(2 \phi 20 \mathrm{~mm})\end{array}$} & \\
\hline RC-200-2 & 14.8 & 24.0 & 21.0 & 2.96 & 47.1 & & \\
\hline RC-200-3 & 15.2 & 23.7 & 20.9 & 2.40 & 48.7 & & \\
\hline
\end{tabular}

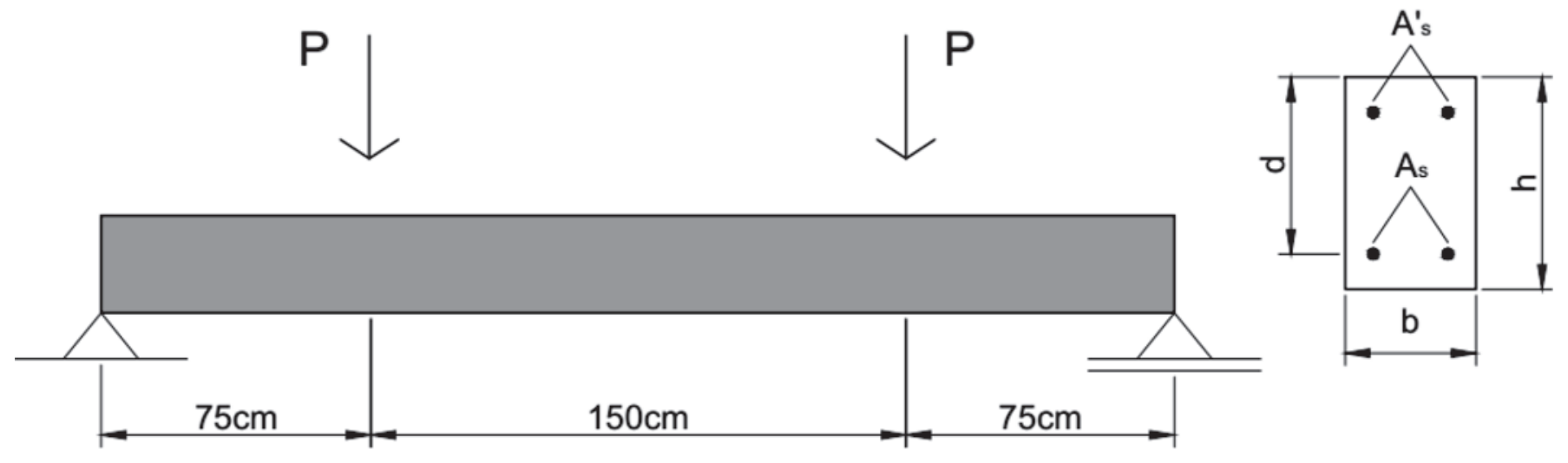

Figure 4.1

Geometry and loading of beams tested by Schegg and Decanini [8]
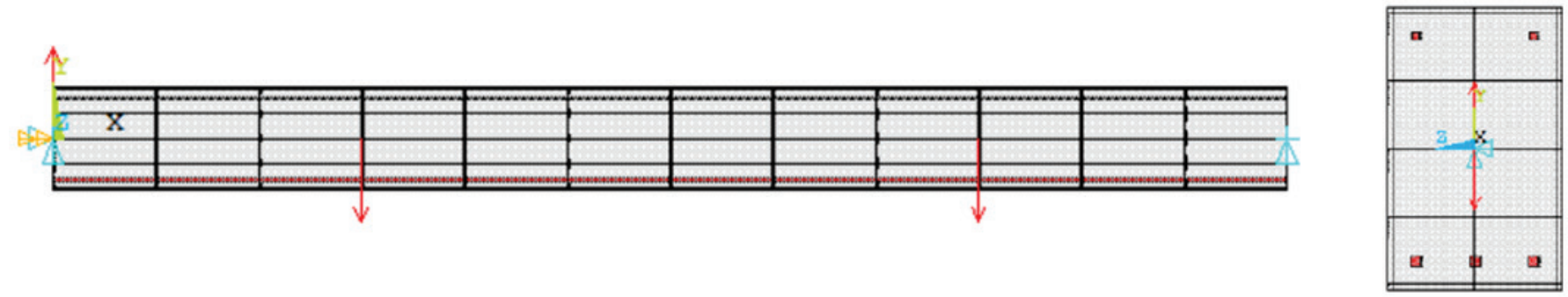

Figure 4.2

Finite element mesh used for analysis and validation of the numerical model 


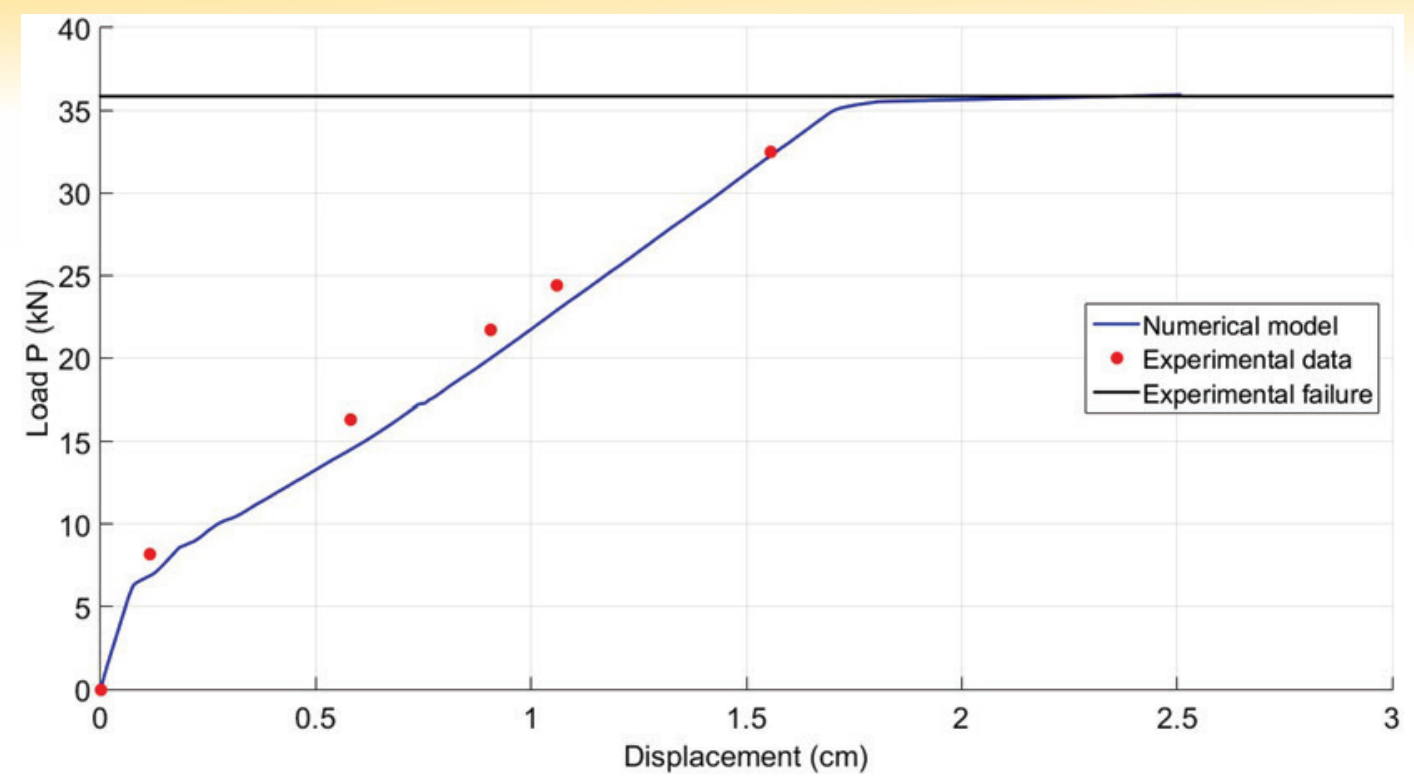

Figure 4.3

Load-displacement plot for the specimen RC-075-1

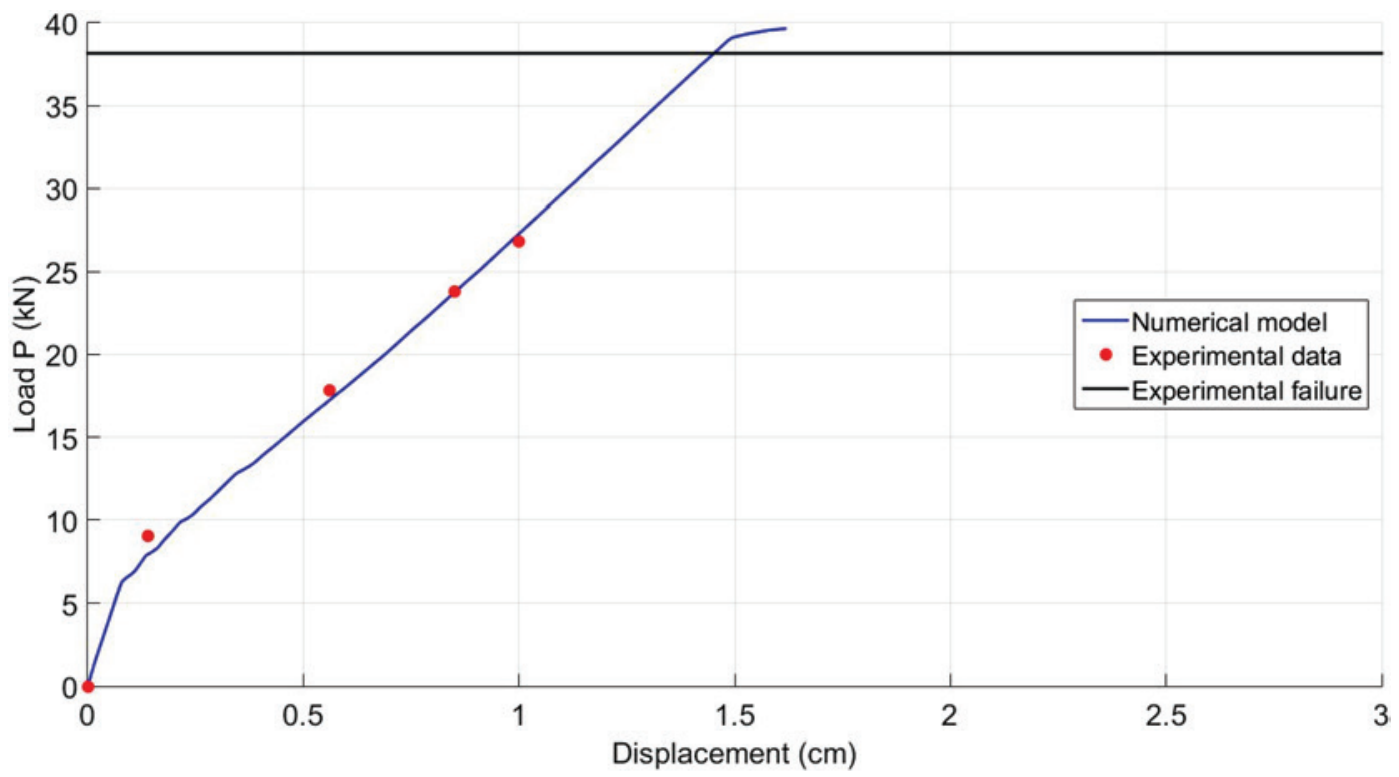

Figure 4.4

Load-displacement plot for the specimen RC-100-1

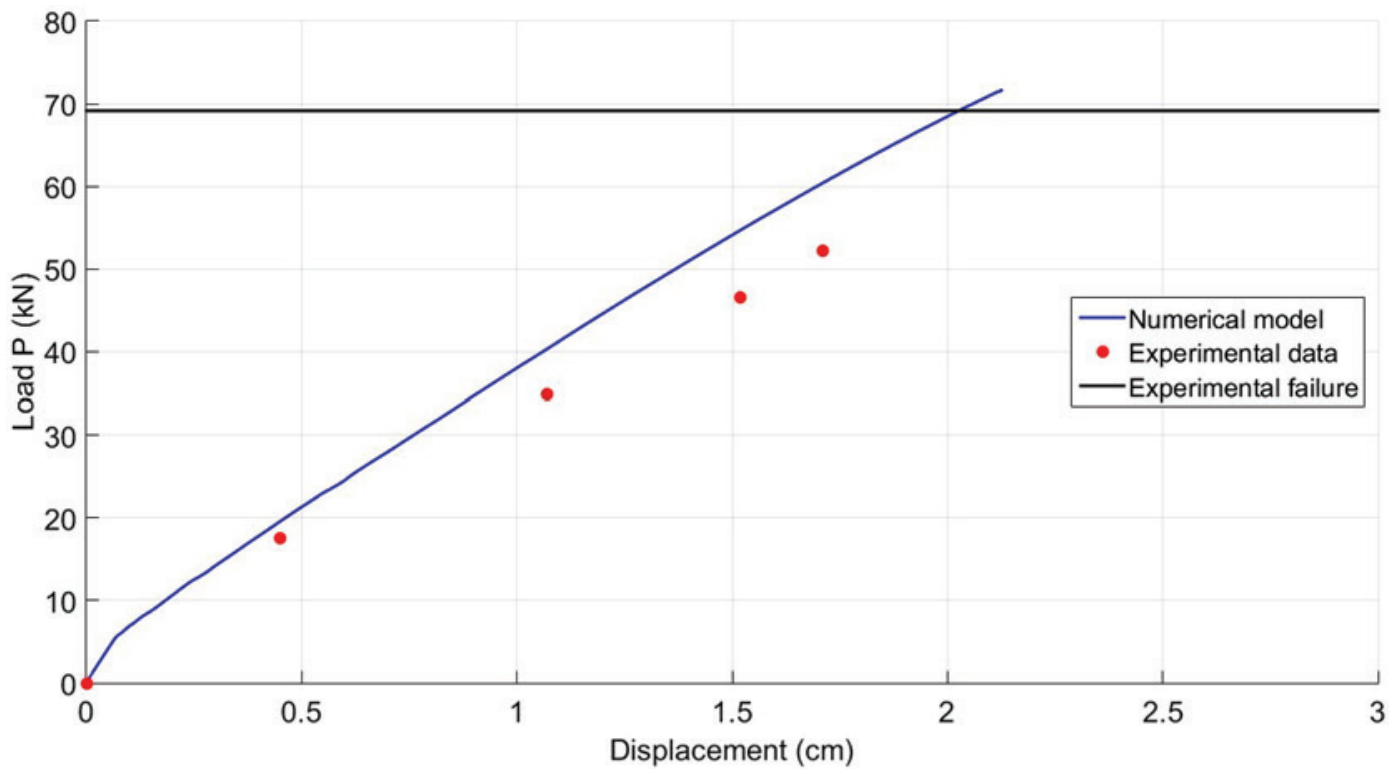

\section{Figure 4.5}

Load-displacement plot for the specimen RC-200-1 
Table 4.2

Ultimate loads obtained experimentally and numerically

\begin{tabular}{cccc}
\hline Beam & $\begin{array}{c}\text { Ultimate } \\
\text { numerical } \\
\text { load - Pn } \\
(\mathrm{kN})\end{array}$ & $\begin{array}{c}\text { Ultimate } \\
\text { experimental } \\
\text { load - } \\
\text { Pe }(\mathrm{kN})\end{array}$ & $\mathrm{Pe} / \mathrm{Pn}$ \\
\hline $\mathrm{RC}-075-1$ & 35.93 & 35.85 & 1.00 \\
$\mathrm{RC}-075-2$ & 34.75 & 35.67 & 1.03 \\
$\mathrm{RC}-075-3$ & 35.72 & 35.67 & 1.00 \\
$\mathrm{RC}-100-1$ & 39.66 & 38.16 & 0.96 \\
$\mathrm{RC}-100-2$ & 38.81 & 38.67 & 1.00 \\
$\mathrm{RC}-100-3$ & 38.35 & 37.41 & 0.98 \\
$\mathrm{RC}-200-1$ & 71.68 & 69.16 & 0.96 \\
RC-200-2 & 69.72 & 67.84 & 0.97 \\
$\mathrm{RC}-200-3$ & 70.88 & 69.16 & 0.98 \\
\hline
\end{tabular}

numerical model satisfactorily represents the non-linear behavior of the beams during loading.

The ultimate loads obtained experimentally and through the numerical model are shown in Table 4.2. It is verified that the finite element model is capable of accurately capturing the expected values in the rupture of the models.

The values presented in Table 4.2 can be statistically evaluated. The mean and standard deviation obtained for the $\mathrm{Pe} / \mathrm{Pn}$ ratio are approximately 0.99 and 0.02 , respectively, reflecting an expected variability between the results obtained experimentally and those obtained through numerical simulation.

\section{Structural reliability}

\subsection{Generalities}

For Nowak and Collins [9], structural reliability is related to the probability that a structure will meet a given limit state during a specific time interval and under certain conditions of use. Considering situations of design of reinforced concrete structures, the reliability of a given structure in relation to an ultimate limit state is related to the probability that this structure does not fail for which it was designed, so that its resistance is greater than imposed loads during its life cycle.

The fact is that most of the phenomena related to engineering present a certain degree of uncertainty, from those related to the properties of the materials used, the active loads and the final geometry. As a result, it becomes impossible to attest to a structure as totally safe, and there is always a probability of finite failure associated with it.

\subsection{Performance function}

One of the initial aspects to be considered in the reliability analysis of a structure is to define a performance function for the failure mode under study. Such a function expresses a relation of capacity versus demand and characterizes the strength of the structure as sufficient or insufficient. Generally, the performance function is expressed by (5.1), where $\mathbf{X}$ corresponds to the vector of basic variables of the model [10].

$\mathrm{g}(\mathbf{X})=\mathrm{g}\left(\mathrm{X}_{1}, \mathrm{X}_{2}, \ldots, \mathrm{X}_{\mathrm{n}}\right)$

Considering a structure with respect to the ultimate limit state, safety is defined from the so-called "safety margin", given by the difference between the carrying capacity of the structure and the load its imposed. In this way, the expression (5.1) is particularized and takes the form given by (5.2).

$\mathrm{g}(\mathrm{R}, \mathrm{S})=\mathrm{R}-\mathrm{S}$

Being $R$ and S resistance and load effect, respectively. From (5.2), the performance of the structure can fit into three possible domains: the safety domain corresponds to values of $g(R, S)>0$, a situation in which the structure is demanded below its resistance; The failure corresponds to the values of $g(R, S)<0$, the structure being demanded beyond its resistance. The limit between failure and safety corresponds to the situation $g(R, S)=0$, being called the limit state [9].

For a model where resistance and load effect are statistically independent random variables with normal probability distribution, we have, as a consequence, a safety margin function also represented by a normal probability distribution, as shown in Figure 5.1. For the particular case presented in Figure 5.1, the probability density function of the safety margin can be defined from the

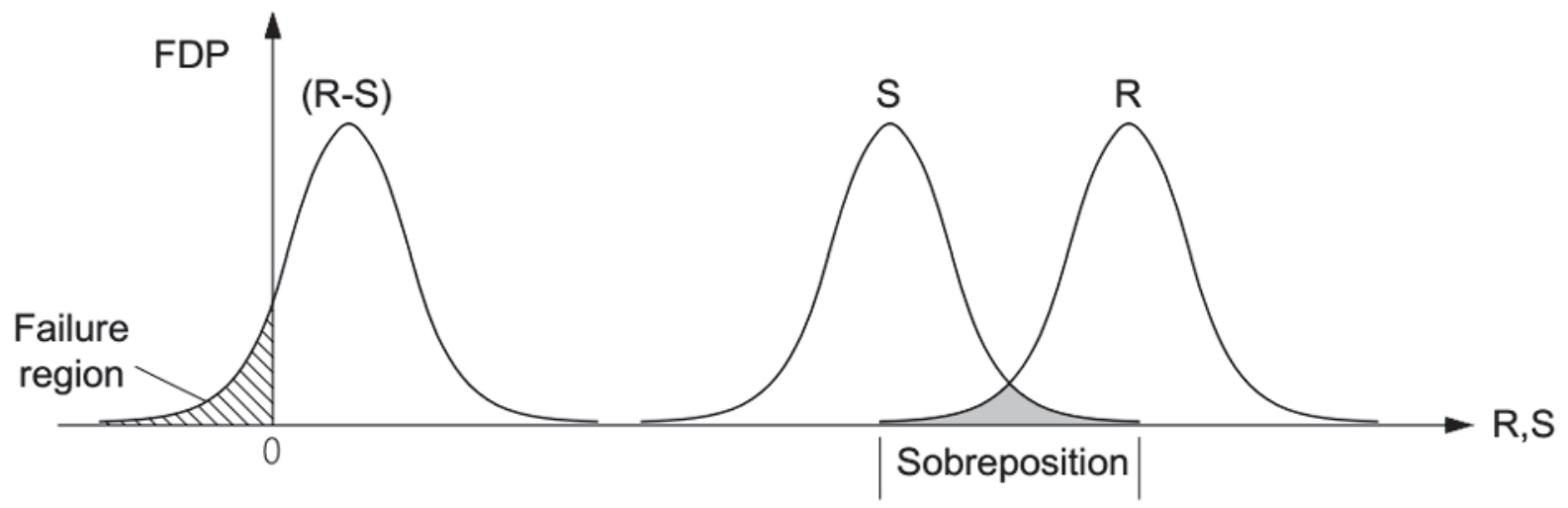

Figure 5.1

Load-displacement plot for the specimen RC-200-1 
statistical moments of resistance and load effect (means $\mu_{\mathrm{R}}$ and $\mu_{\mathrm{S}}$; standard deviations $\sigma_{\mathrm{R}}$ and $\sigma_{\mathrm{S}}$ ) according to expressions (5.3) and (5.4), being the probability of failure of the model obtained by (5.5), where $\Phi$ is the cumulative distribution function for a standard normal random variable.

$\mu_{\mathrm{M}}=\mu_{\mathrm{R}}-\mu_{\mathrm{S}}$

$\sigma_{\mathrm{M}}=\sqrt{\sigma_{\mathrm{R}}^{2}+\sigma_{\mathrm{S}}^{2}}$

$\mathrm{p}_{\mathrm{f}}=\Phi\left(-\frac{\mu_{\mathrm{M}}}{\sigma_{\mathrm{M}}}\right)$

In engineering problems, in general, the safety level of a structure in relation to a given limit state is evaluated through the so-called reliability index $\beta$. In situations where the safety margin presents a normal probability distribution, the reliability index can be obtained directly by the expression (5.6).

$\beta=\frac{\mu_{M}}{\sigma_{M}}$

\subsection{The Monte Carlo Method}

The simulation technique applied to engineering consists in the elaboration of a mathematical model with the intention of reproducing the real behavior of a structure, allowing to evaluate the variability of the ultimate load, for example, before the introduction of randomness in the input parameters, such as properties of materials and geometric characteristics. The Monte Carlo Method, in this context, has been widely used, especially for its simplicity and for not demanding more complex knowledge in probability and statistics [10].

Haldar and Mahadevan [10] describe the six essential elements associated with the Monte Carlo method, presented below:

1. Define the problem in terms of the random variables;

2. Determine the probability distributions and the main statistics of the random variables involved in the problem;

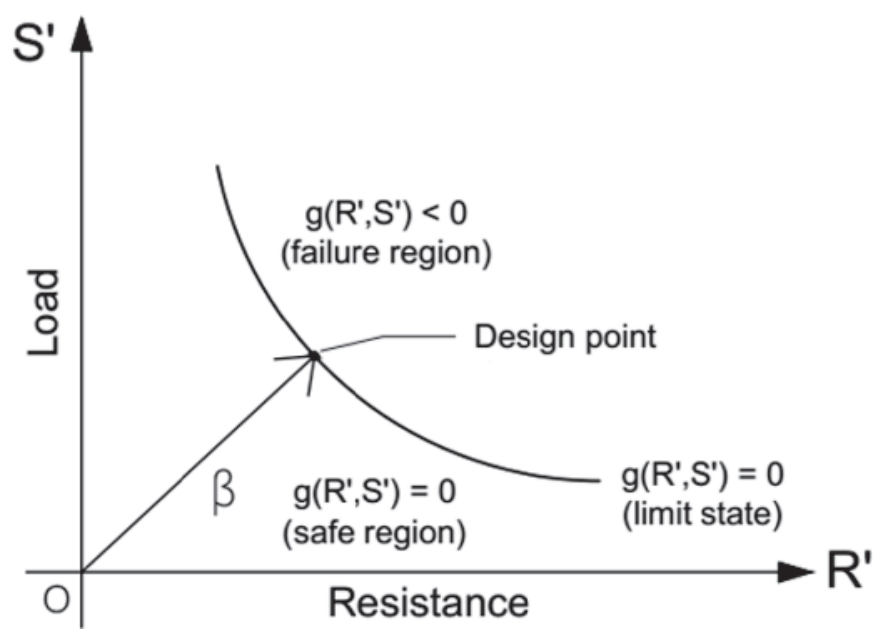

Figure 5.2

Geometric interpretation of the reliability index (adapted from Haldar and Mahadevan, [10])
3. Generate a set of values for the random variables according to their probability distributions;

4. Solve the model deterministically for the set of values of the random variables;

5. Extract the statistical information after $\mathrm{N}$ simulations;

6. Determine the efficiency of the simulation process.

In this work, the Monte Carlo method is used as a tool for statistical inference of the resistance $R$ that composes the function $g(R, S)$. For the numerical model employed, a sufficient number of simulations are performed to obtain the convergence of the statistical moments of the resistant models, thus determining the probability density function $f_{R}(r)$ by adjusting the set of obtained data.

\subsection{Reliability Index and FORM}

In many practical cases, where the performance function is complex, not being possible to guarantee the normality of the margin of safety variable, the simple use of the expression (5.6) can lead to errors in the reliability index estimation. In this context, the FORM (First-Order Reliability Method) has been widely used to obtain the $\beta$ index.

In the space of normal standard variables, the reliability index can be obtained by the geometric interpretation of the performance function. In Figure 5.2, $\beta$ corresponds to the shortest distance from the system origin of the normal random variables space to the limit state function $g\left(R^{\prime}, S^{\prime}\right)=0$, from which the failure region starts. For a generic variable $X_{i}$, this can be represented in the system of the normal random variables according to (5.7).

$\mathrm{X}_{\mathrm{i}}=\mu_{\mathrm{X}}^{\mathrm{E}}+\mathrm{X}_{\mathrm{i}}{ }^{\prime} \sigma_{\mathrm{X}}^{\mathrm{E}}$

In the above expression, the " $E$ " index in the mean and standard deviation values indicates whether it is equivalent normal function values for variables with a probability distribution other than normal. Since the distance between the origin and a given point in the reduced system of the normal random variables given by $\mathrm{D}=\sqrt{\mathbf{X}^{\prime} \mathbf{T}^{\prime}}$, the determination of the reliability index consists of minimizing distance $D$ following the constraint $g(X)=0$. The point on the failure surface $g\left(\mathbf{X}^{\prime}\right)=0$ associated with the shortest distance is called the most problabe point or design point, being expressed by $\mathbf{x}^{\prime *}$. The reliability index of the system is obtained by (5.8).

$\beta=-\frac{\sum_{\mathrm{i}=1}^{\mathrm{n}} \mathrm{x}^{\prime *}{ }_{\mathrm{i}}\left(\frac{\partial \mathrm{g}}{\partial \mathrm{X}_{\mathrm{i}}^{\prime}}\right)^{*}}{\sqrt{\sum_{\mathrm{i}=1}^{\mathrm{n}}\left(\frac{\partial \mathrm{g}}{\partial \mathrm{X}_{\mathrm{i}}^{\prime}}\right)^{2 *}}}$

In the expression (5.8), the notation '*' indicates that the vector of the random variables and the partial derivatives are evaluated at the design point. As this point is not known a priori, the value of $\beta$ is obtained by successive approximations. The directional cosine. for each variable is given by (5.9), being the design point $x^{1 *}{ }_{i}$ of the respective variable in the reduced system obtained by (5.10).

$\alpha_{\mathrm{i}}=\frac{\left(\frac{\partial \mathrm{g}}{\partial \mathrm{X}_{\mathrm{i}}^{\prime}}\right)^{*}}{\sqrt{\sum_{\mathrm{i}=1}^{\mathrm{n}}\left(\frac{\partial \mathrm{g}}{\partial \mathrm{X}_{\mathrm{i}}^{\prime}}\right)^{2 *}}}$

$\mathrm{x}^{\prime}{ }_{\mathrm{i}}=-\alpha_{\mathrm{i}} \beta$ 
For variables that do not present a normal probability distribution, we can use the Rackwitz and Fiessler procedure, presented in Nowak and Collins [9], to determine the mean and standard deviation values of an equivalent normal variable at the design point given the cumulative probability distribution functions $F_{x}(x)$ and the original probability density $f_{x}(x)$ of the variable. Expressions (5.11) and (5.12) are used to determine the mean and standard deviation values of the equivalent normal function, $\mu_{\mathrm{x}}{ }^{\mathrm{E}}$ and $\sigma_{\mathrm{x}}{ }^{\mathrm{E}}$, respectively.

$\mu_{\mathrm{X}}^{\mathrm{E}}=\mathrm{x}^{*}-\sigma_{\mathrm{X}}^{\mathrm{E}}\left\{\Phi^{-1}\left[\mathrm{~F}_{\mathrm{X}}\left(\mathrm{x}^{*}\right)\right]\right\}$

$\sigma_{\mathrm{X}}^{\mathrm{E}}=\frac{1}{\mathrm{f}_{\mathrm{X}}\left(\mathrm{x}^{*}\right)} \phi\left\{\Phi^{-1}\left[\mathrm{~F}_{\mathrm{X}}\left(\mathrm{x}^{*}\right)\right]\right\}$

Where $\Phi$ and $\varphi$ correspond to the cumulative probability distribution function and the probability density function of a standard normal variable, respectively.

\section{Probabilistic analysis of reinforced concrete beams}

\subsection{Characterization of the beams}

In this work the reliability indexes obtained for a simple supported beam model with rectangular section, shown in Figure 6.1, in which the tensioned and compressed reinforcement are also presented generally. The beam in question has a fixed span of $500 \mathrm{~cm}$ and a width of $20 \mathrm{~cm}$, being subjected to a characteristic distributed load, consisting of a permanent and live portion.
In this study four parameters are considered in the characterization of the model, being the characteristic strength of the concrete $\left(f_{c k}=25 ; 35 ; 45 \mathrm{MPa}\right)$, the section height $(\mathrm{h}=40 ; 50 ; 60 \mathrm{~cm})$, the load ratio $\left(r=q_{k} / g_{k}=0,5 ; 1,0 ; 2,0\right)$ and the total characteristic load $\left(p_{k}=15 ; 20 ; 25 \mathrm{kN} / \mathrm{m}\right)$. Three different values are considered for each parameter, resulting in a set of 81 beams identified according to the nomenclature $V-f_{c k}-h-r-p_{k}$. The reinforcement were designed for each of the 81 beams, according to their geometry, mechanical properties of materials and characteristic load, according to the design procedures presented in item 2 .

\subsection{Random variables considered}

A set of ten random variables was considered to represent the uncertainties involved in the problem under study. The distributions adopted, as well as the statistical parameters of the random variables were extracted from the works of Silva [11], Santos et al. [12], Real [1], Nowak and Collins [9] and Galambos et al. [13].

Among the total number of random variables, six were used in the numerical simulation of the beams and, therefore, they characterize the probability distribution obtained for the resistance $\mathrm{R}$ of the models in question. Table 6.1 shows the random variables considered in the finite element model and their respective probability distributions.

The other random variables, corresponding to the loads and model uncertainty variables are presented in Table 6.2. These variables compose, along with the variable corresponding to the resistance, the performance function used to obtain the reliability index.

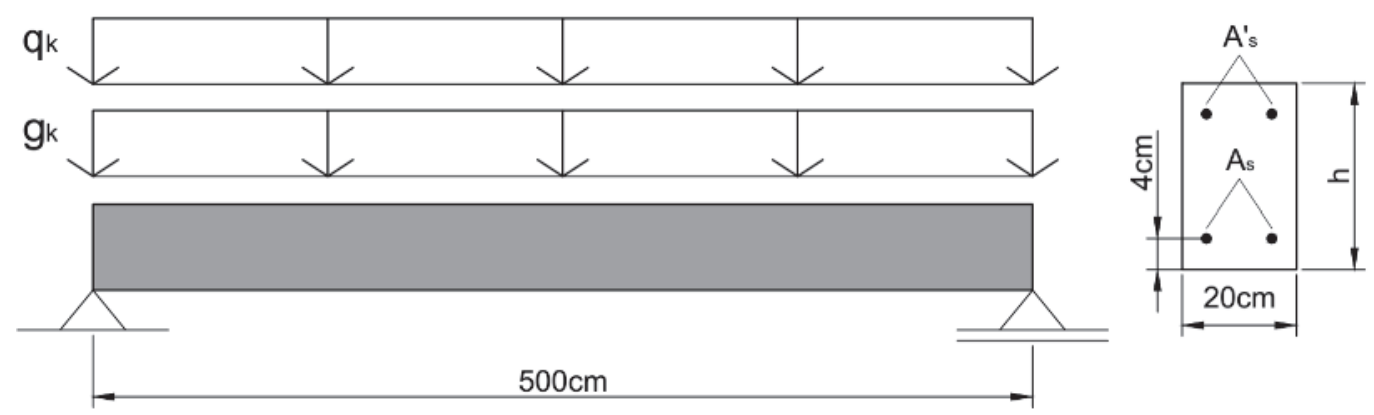

Figure 6.1

Geometry, loading and boundary conditions of the studied beam

Table 6.1

Random variables associated with resistance, used in numerical simulations

\begin{tabular}{|c|c|c|c|c|c|}
\hline Variable & Description & Distrib. & $\mu_{\mathrm{x}}$ & $\mathbf{V}_{\mathrm{x}}$ & Ref. \\
\hline$f_{c}$ & Compressive strength of concrete & Normal & $\mathrm{f}_{c k} /\left(1-1.645 V_{x}\right)$ & 0.1 & {$[1] \cdot[12]$} \\
\hline$f_{c t}$ & Tensile strength of concrete & Normal & \multirow{2}{*}{ Note "a" } & 0.1 & \multirow{2}{*}[1]{} \\
\hline $\mathrm{E}_{\mathrm{c}}$ & Young's modulus of concrete & Normal & & 0.1 & \\
\hline$f_{y}$ & Yield stress of reinforcement & Normal & $\mathrm{f}_{\mathrm{yk}} /\left(1-1.645 \mathrm{~V}_{\mathrm{x}}\right)$ & 0.05 & [1]. [12] \\
\hline $\mathrm{h}$ & Cross section height & Normal & Nominal value & $0.5 / \mu_{\mathrm{x}}$ & \multirow[b]{2}{*}[1]{} \\
\hline$d^{\prime}$ & $\begin{array}{l}\text { Distance of the reinforcement to the } \\
\text { underside beam section }\end{array}$ & Normal & $4 \mathrm{~cm}$ & $0.5 / \mu_{x}$ & \\
\hline
\end{tabular}

a) Average values determined according to fib 2010 model code, as a function of the class of concrete used. 


\subsection{Performance function and resistance statistics}

The performance function adopted in this work takes the form presented in (6.1).

$\mathrm{g}(\mathbf{X})=\theta_{\mathrm{R}} \mathrm{R}-\theta_{\mathrm{S}}(\mathrm{G}+\mathrm{Q})$
The Monte Carlo method is used to obtain the random variable $\mathrm{R}$, which corresponds to the resistence of the beam in terms of the maximum distributed load supported in the numerical model. The mean and standard deviation of the resistance are obtained from a sufficient number of simulations, which is defined when the

\section{Table 6.2}

Random variables employed in the calculation of $\beta$ by FORM

\begin{tabular}{|c|c|c|c|c|c|}
\hline Variable & Description & Distrib. & $\mu_{\mathrm{x}}$ & $\mathbf{V}_{\mathbf{x}}$ & Ref. \\
\hline R & Resistance of the beam & \multicolumn{4}{|c|}{ (Adjusted according to data obtained through simulation) } \\
\hline G & Dead load & Normal & $1.05 g_{k}$ & 0.10 & [13] \\
\hline Q & Live load & Gumbel & $\mathrm{q}_{\mathrm{k}} /\left(1+0.35 \mathrm{~V}_{\mathrm{x}}\right)$ & 0.25 & {$[11] .[13]$} \\
\hline$\theta_{\mathrm{R}}$ & $\begin{array}{l}\text { Uncertainty parameter } \\
\text { of the resistant model }\end{array}$ & Lognormal & 1.0 & 0.05 & [12] \\
\hline$\theta_{\mathrm{S}}$ & Uncertainty parameter of the load model & Lognormal & 1.0 & 0.05 & [12] \\
\hline
\end{tabular}

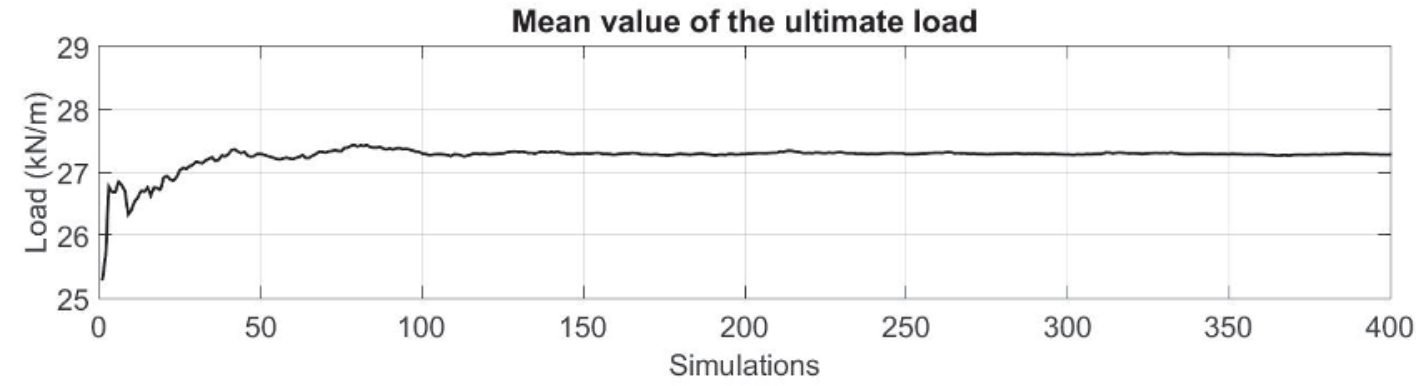

Standard desviation value of the ultimate load

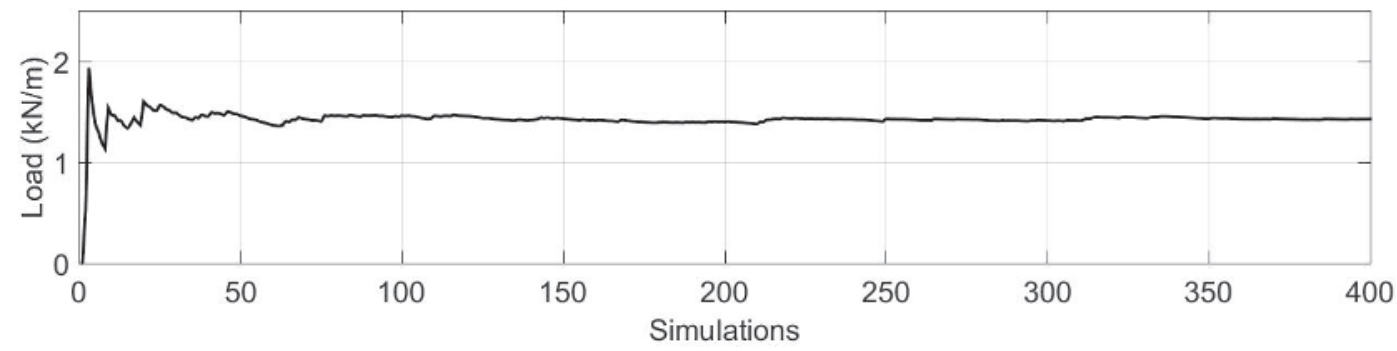

Figure 6.2

Statistical convergence of the parameters of resistance
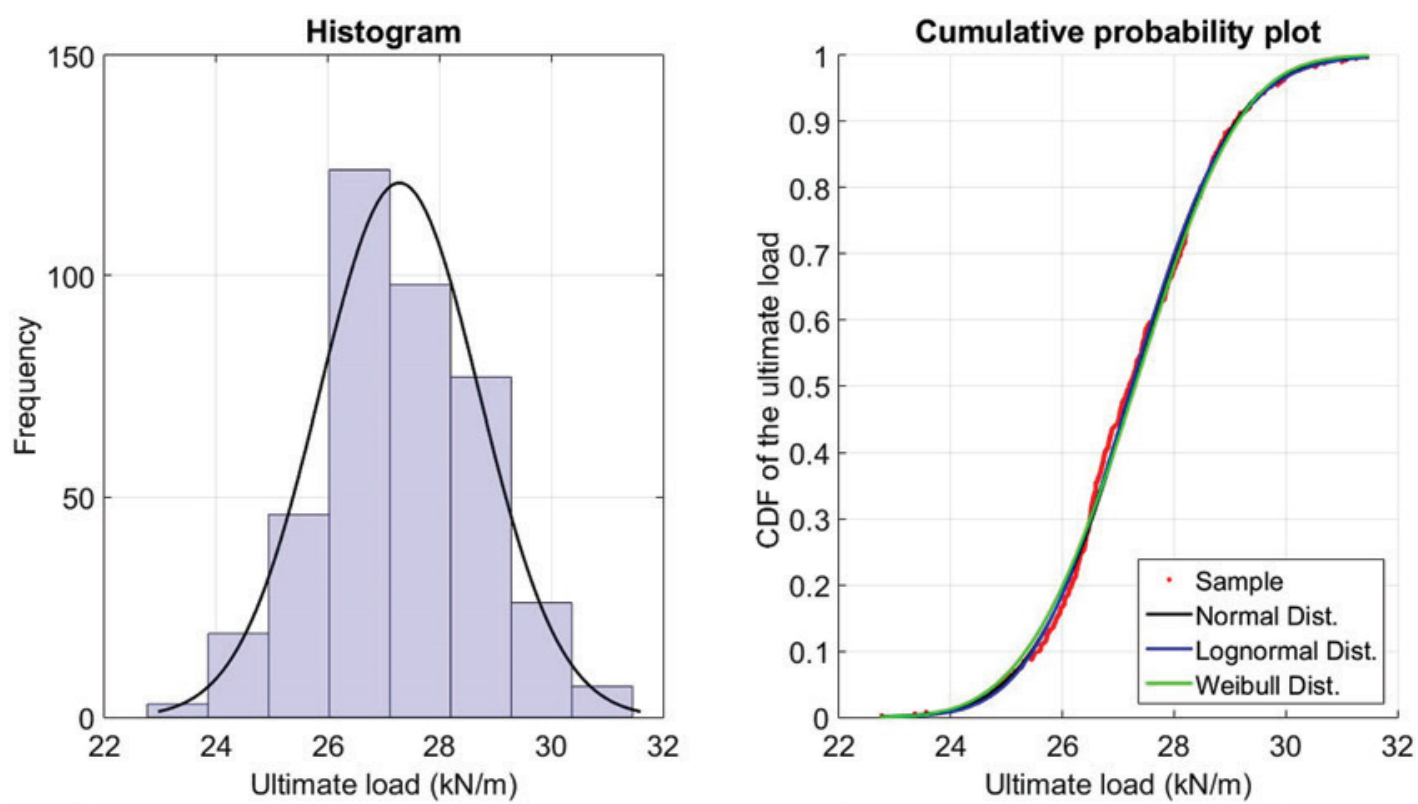

Figure 6.3

Distributions fitness for resistance of the beam V-25-40-r-15 (400 simulations) 
statistical convergence of the data is reached. Figure 6.2 shows the statistical convergence of the mean and standard deviation of the beam resistance V-25-40-r-15 for a total of 400 simulations.

For the reliability study, the resistance data set of each model was adjusted according to a known theoretical probability distribution. This procedure has already been employed by other authors, citing the works developed by Szerszen and Nowak [17], Diniz and
Frangopol [18], Real [1], Szerszen et al [19], Ferreira et al [20] and Magalhães et al [21].

Normal, Lognormal and Weibull probability distributions were used initially to adjust the resistance data obtained through simulation. The quality of these adjustments was verified through the Kolmogorov-Smirnov and Anderson-Darling goodness-of-fit tests [22] at a significance level of $5 \%$. Figures 6.3 to 6.5 show the histograms and cumulative probability plots
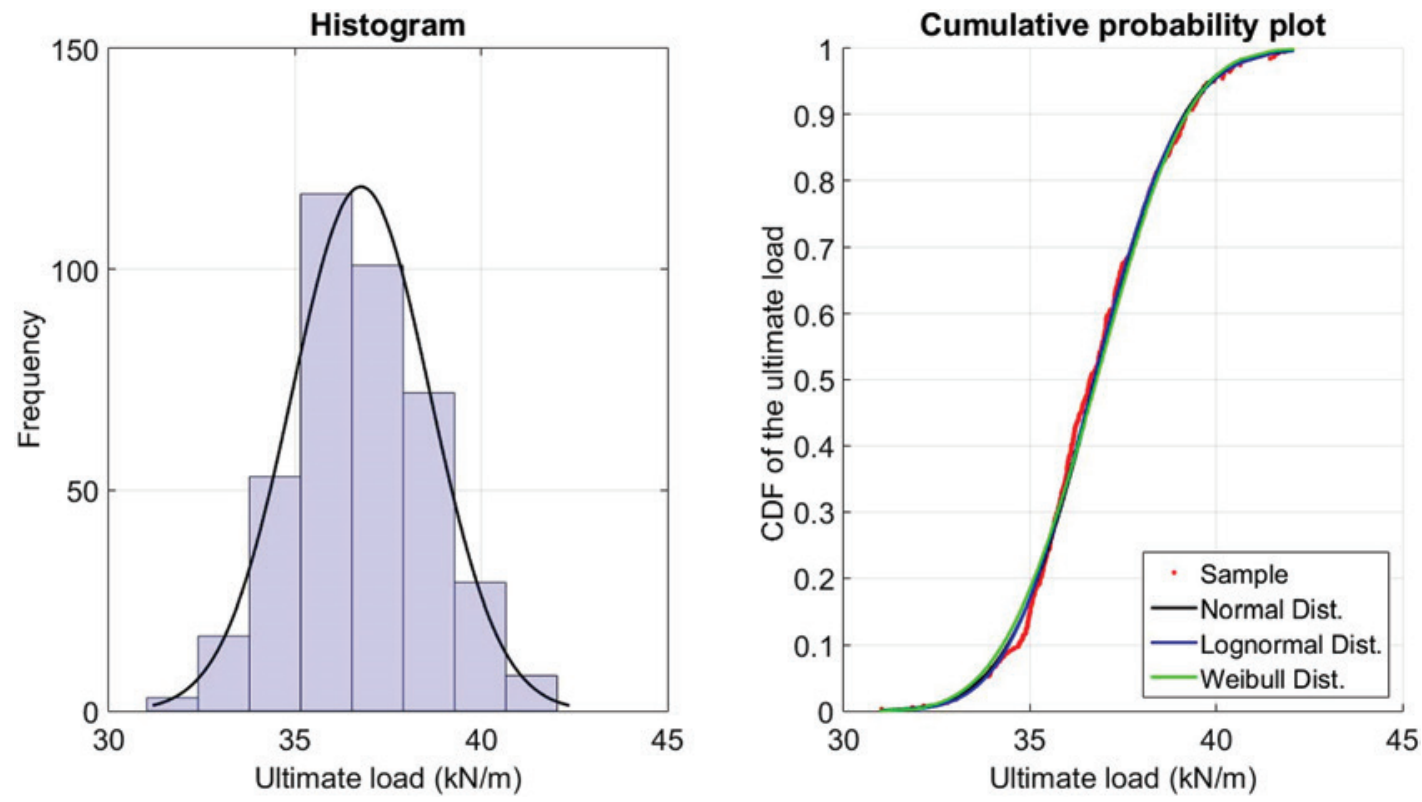

\section{Figure 6.4}

Distributions fitness for resistance of the beam V-25-40-r-20 (400 simulations)
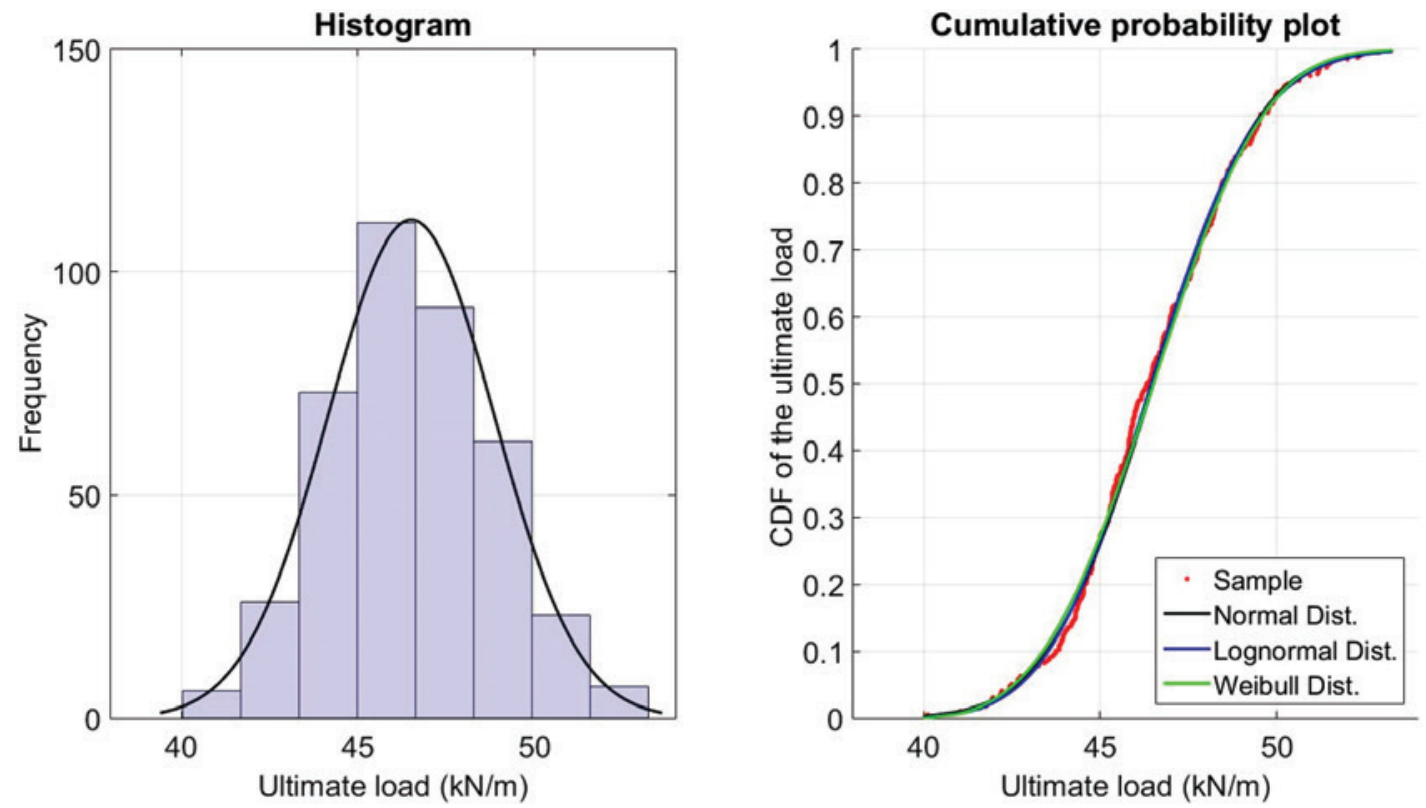

Figure 6.5

Distributions fitness for resistance of the beam V-25-40-r-25 (400 simulations) 
obtained through 400 simulations for the beams with a compressive strength of $25 \mathrm{MPa}$ and a height of $40 \mathrm{~cm}$, designed for the characteristic loads of $15 \mathrm{kN} / \mathrm{m}, 20 \mathrm{kN} / \mathrm{m}$ and $25 \mathrm{kN} / \mathrm{m}$, respectively.

It is observed that the three theoretical distributions attributed lead to a very similar adjustment quality. In order to evaluate the interference of the number of simulations in the quality of the adjustments, and consequently in the reliability study, a total of 1200 simulations were performed for the same beams mentioned above, being the new plots presented in Figures 6.6 to 6.8 .

It is observed that an increase in the number of simulations improves the fit of the data to the assigned theoretical probability distributions. This behavior is expected since, in the case of a random process, a larger number of simulations will lead to a better distributed and more representative dataset for the characterization of the probability distribution [10]. Using the function
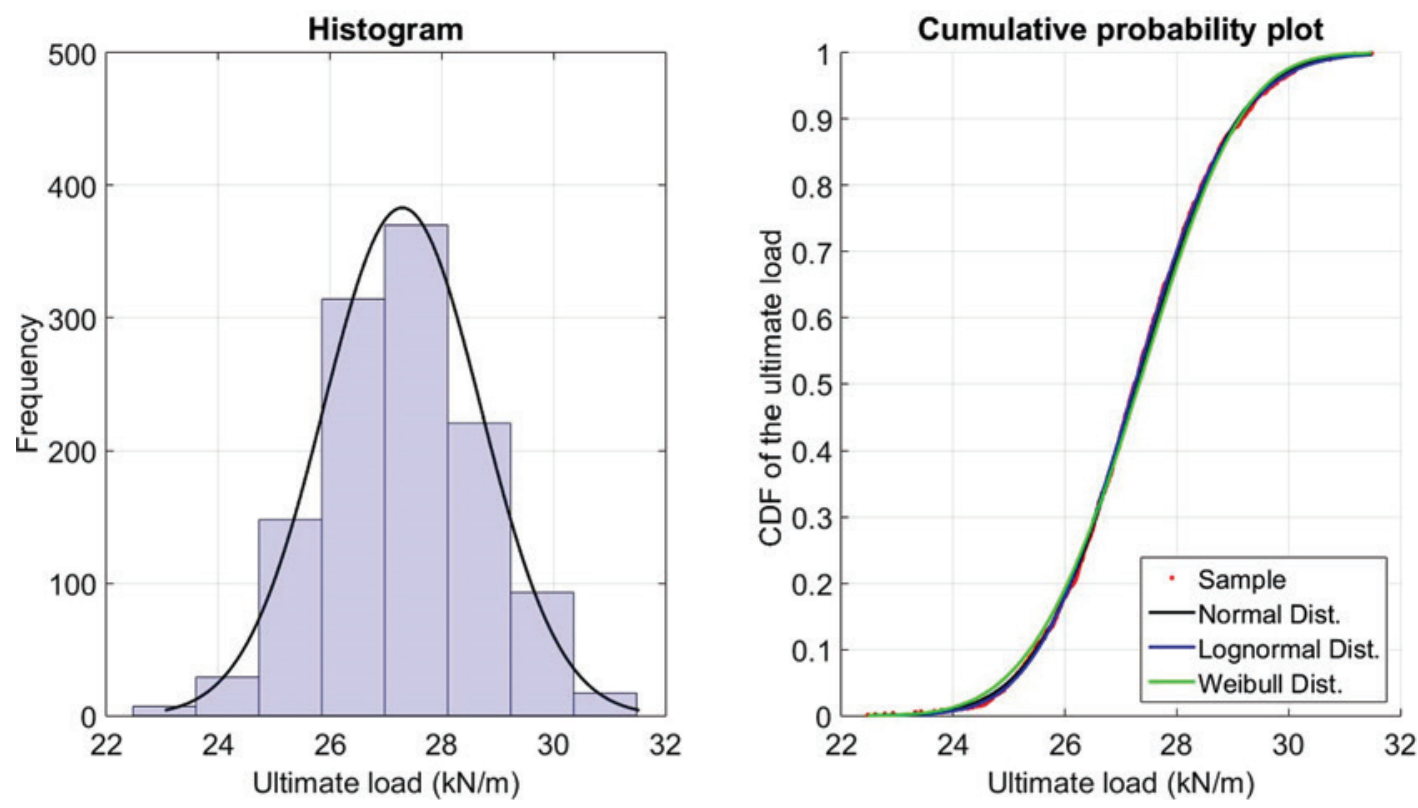

Figure 6.6

Distributions fitness for resistance of the beam V-25-40-r-15 (1200 simulations)
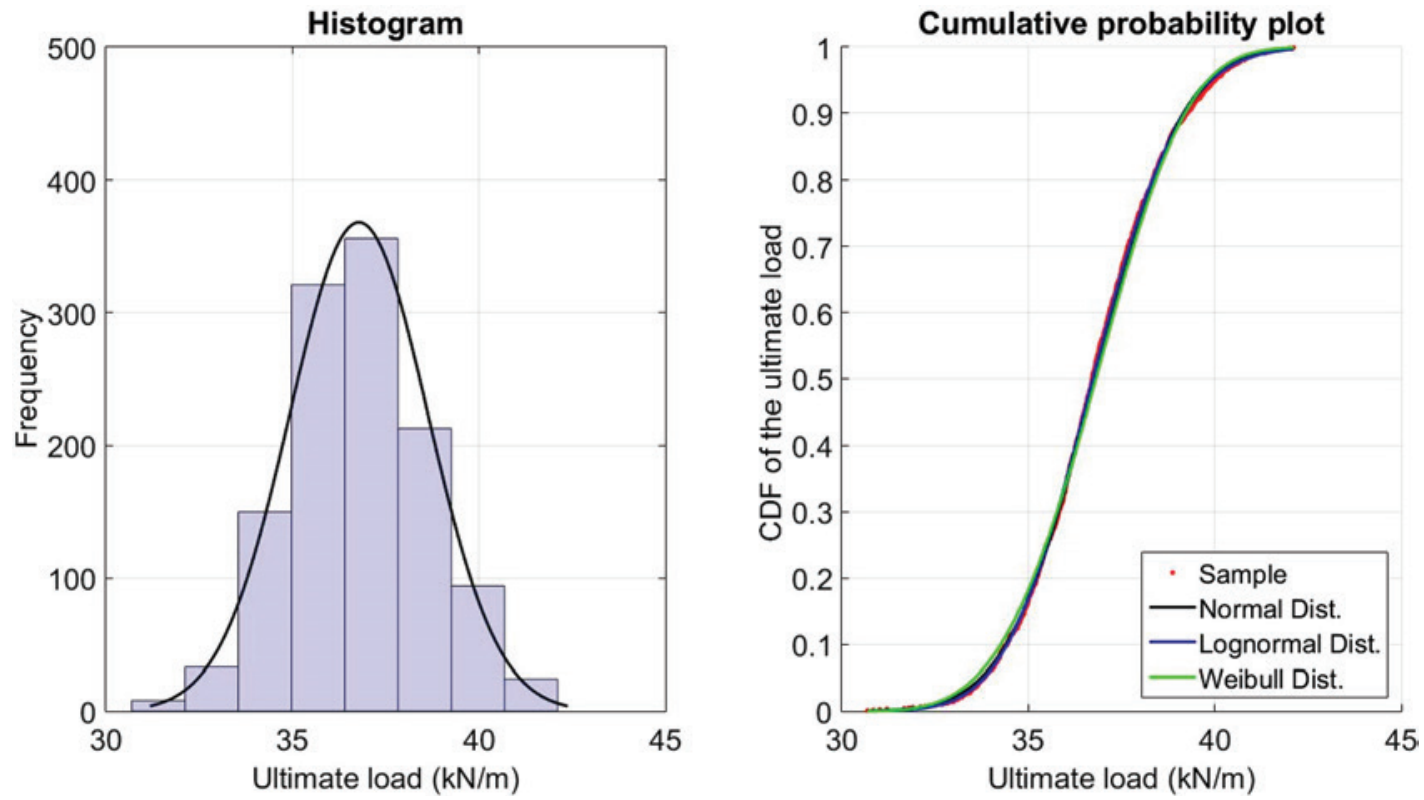

Figure 6.7

Distributions fitness for resistance of the beam V-25-40-r-20 (1200 simulations) 
Reliability of reinforced concrete beams designed in accordance with Brazilian code NBR-6118:2014

given in (6.1), the reliability indexes for the same three beams were calculated, and these are presented in Table 6.3. For this, it was considered the three probability distributions cited and a total of 400 and 1200 simulations.

For each of the assigned distributions, it is verified that the in- crease in the number of simulations does not promote appreciable changes in the reliability indexes. This is due to the fact that the adjustment to the distributions is carried out fundamentally through the statistical moments from the data obtained through simulation. Therefore, once convergence is reached, no significant changes

\section{Table 6.3}

Values of $\beta$ as a function of the probability distribution adopted and number of simulations

\begin{tabular}{|c|c|c|c|c|c|c|}
\hline \multirow{3}{*}{ Beam } & \multicolumn{6}{|c|}{ Distribuition } \\
\hline & Normal & Lognormal & Weibull & Normal & Lognormal & Weibull \\
\hline & \multicolumn{3}{|c|}{400 simulations } & \multicolumn{3}{|c|}{1200 simulations } \\
\hline V-25-40-r-15 & 4.08 & 4.08 & 4.06 & 4.08 & 4.09 & 4.06 \\
\hline V-25-40-r-20 & 4.15 & 4.16 & 4.13 & 4.16 & 4.16 & 4.13 \\
\hline V-25-40-r-25 & 4.22 & 4.22 & 4.21 & 4.22 & 4.22 & 4.20 \\
\hline
\end{tabular}
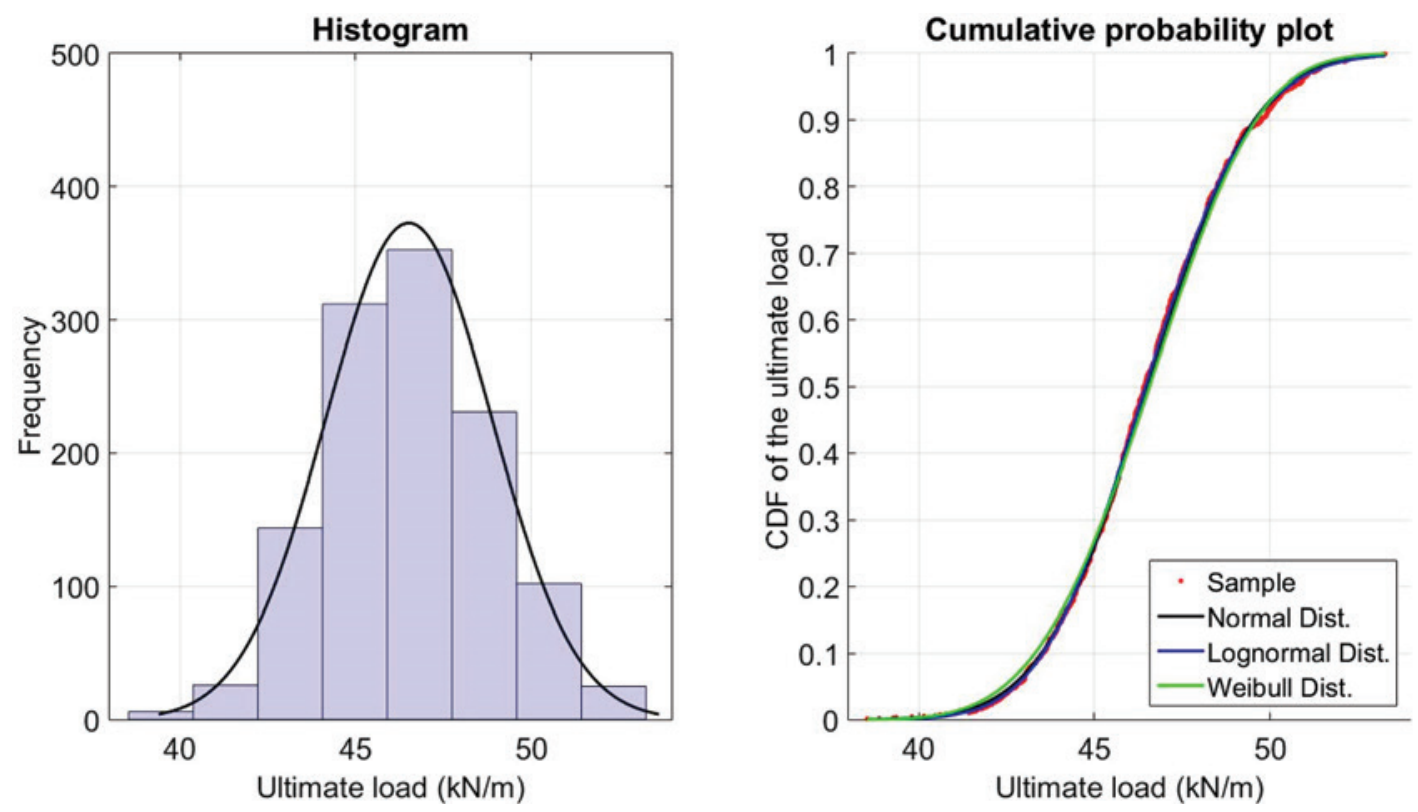

\section{Figure 6.8}

Distributions fitness for resistance of the beam V-25-40-r-25 (1200 simulations)
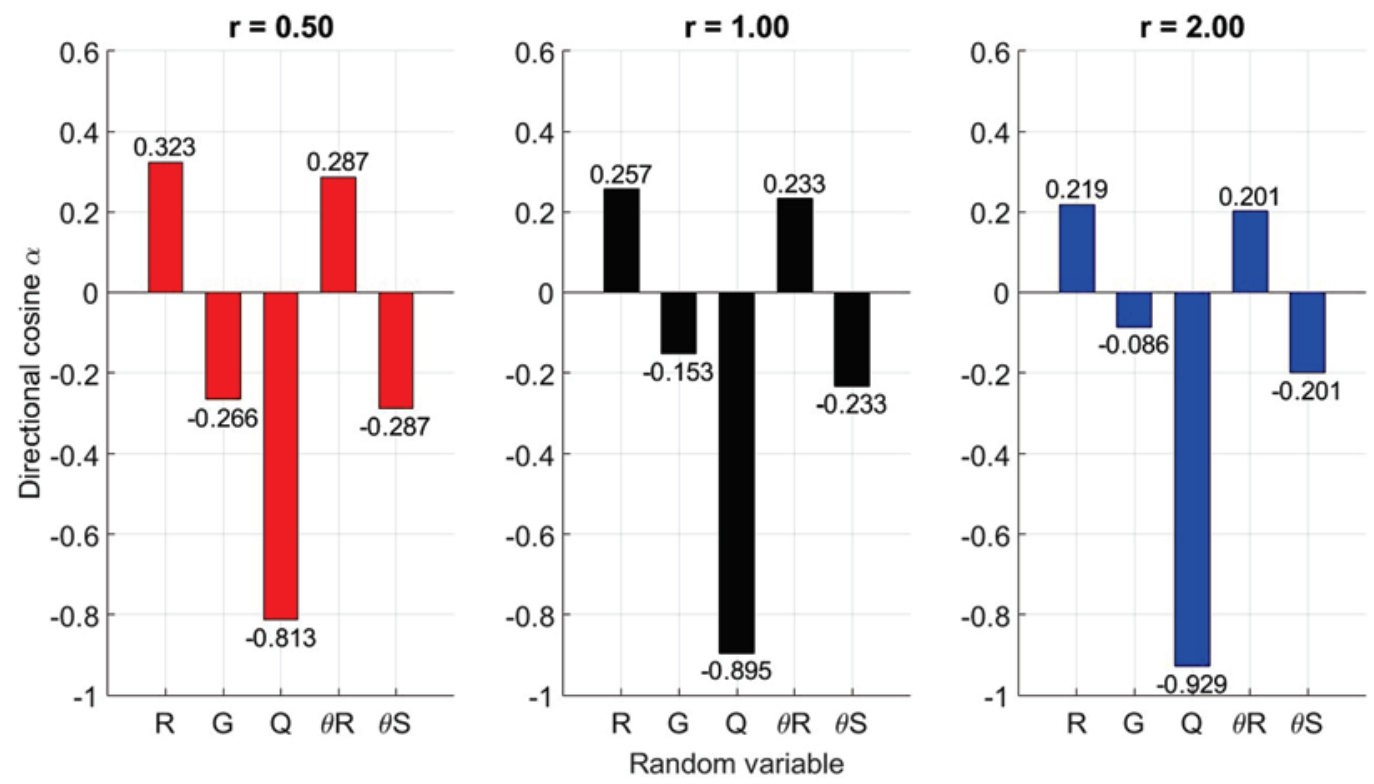

Figure 6.9

Directional cosines obtained via FORM for the beam V-25-40-r-15 
are expected in the reliability indices evaluated, although a better fit is observed in the plots of cumulative probability.

Regarding the types of distributions, it is observed that the differences in reliability indexes are not representative. Therefore, there is no evidence of more accurate results in relation to any of the presented distributions, it was chosen to represent the resistance of the models according to a normal probability distribution. Figure 6.9 shows, for the case of beam V-25-40-r-15, the directional cosines obtained for the solution of the perfomance function (6.1) by FORM.

It is easily observed that for all load ratios $r$, the predominant directing cosine is that of the random variable $Q$, which corresponds to the accidental portion of the load. This implies a large influence of the variable $Q$ on the reliability indexes, as presented in the parametric study of the subsequent item. In relation to the other random variables $\left(R, G, \theta_{R}\right.$ and $\left.\theta_{S}\right)$, it is verified that its directors cosines have similar orders of magnitude among them, indicating that these variables present similar influences on the values of reliability indexes reached. In this condition, and considering the results presented in Table 6.3, it is verified that any errors inherent to the adjustment of the data of the resistance $R$, or even the expected differences using different theoretical distributions for $\mathrm{R}$, do not reflect, in an isolated way, in variations reliability indices. Obviously, such a procedure is valid provided that for a given confidence interval a quality in the adjustment of the theoretical distribution of $\mathrm{R}$ to the data obtained through simulation is ascertained, as verified in this work through goodness-of-fit tests.

\section{Parametric study}

Based on the numerical model and probabilistic fundamentals discussed above, the reliability index was obtained for each of the 81 beams dimensioned according to NBR-6118: 2014. For the purpose of evaluating the safety level associated to the NBR-6118: 2014 design recommendations, the target reliability index presented by the
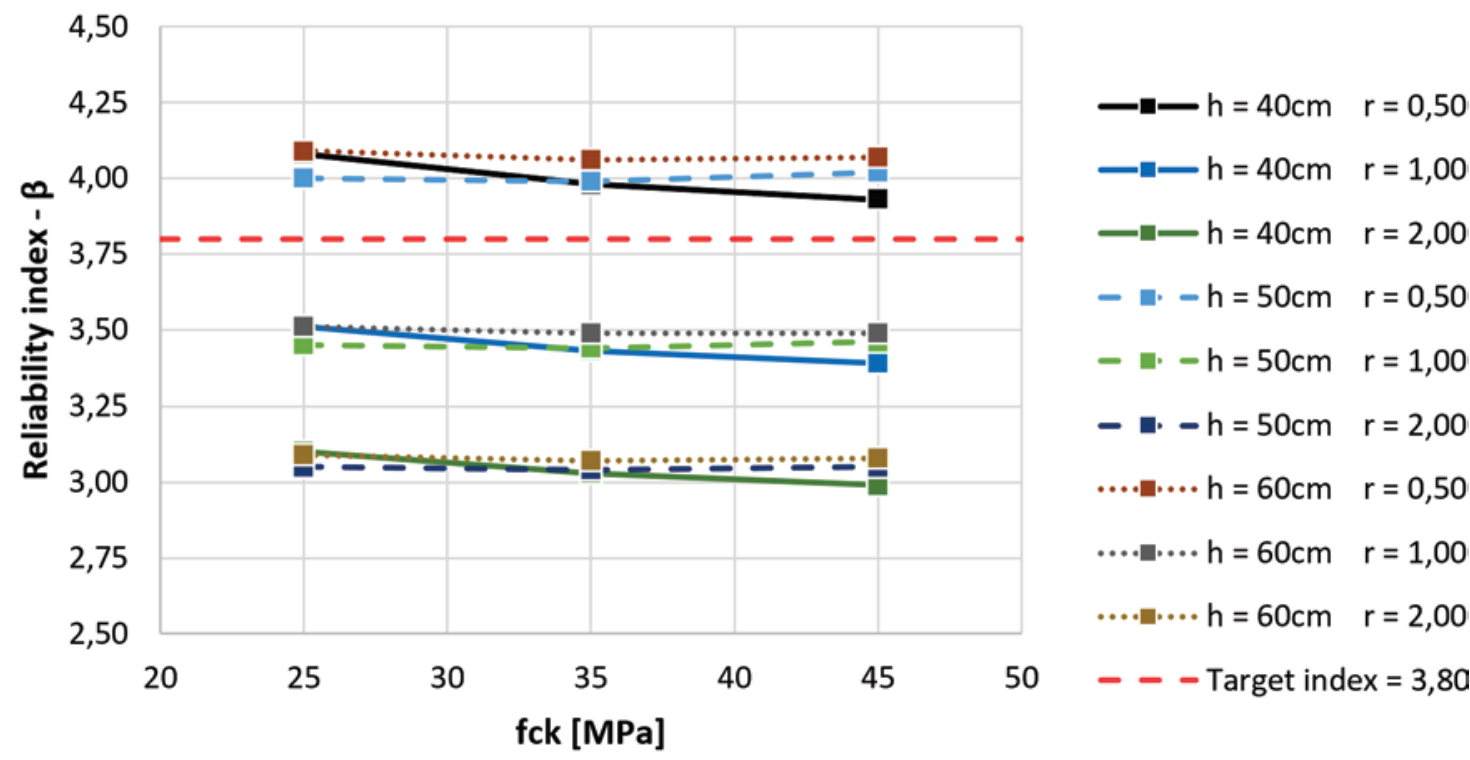

Figure 7.1

Variation of the reliability index as a function of fck $(p k=15 \mathrm{kN} / \mathrm{m})$
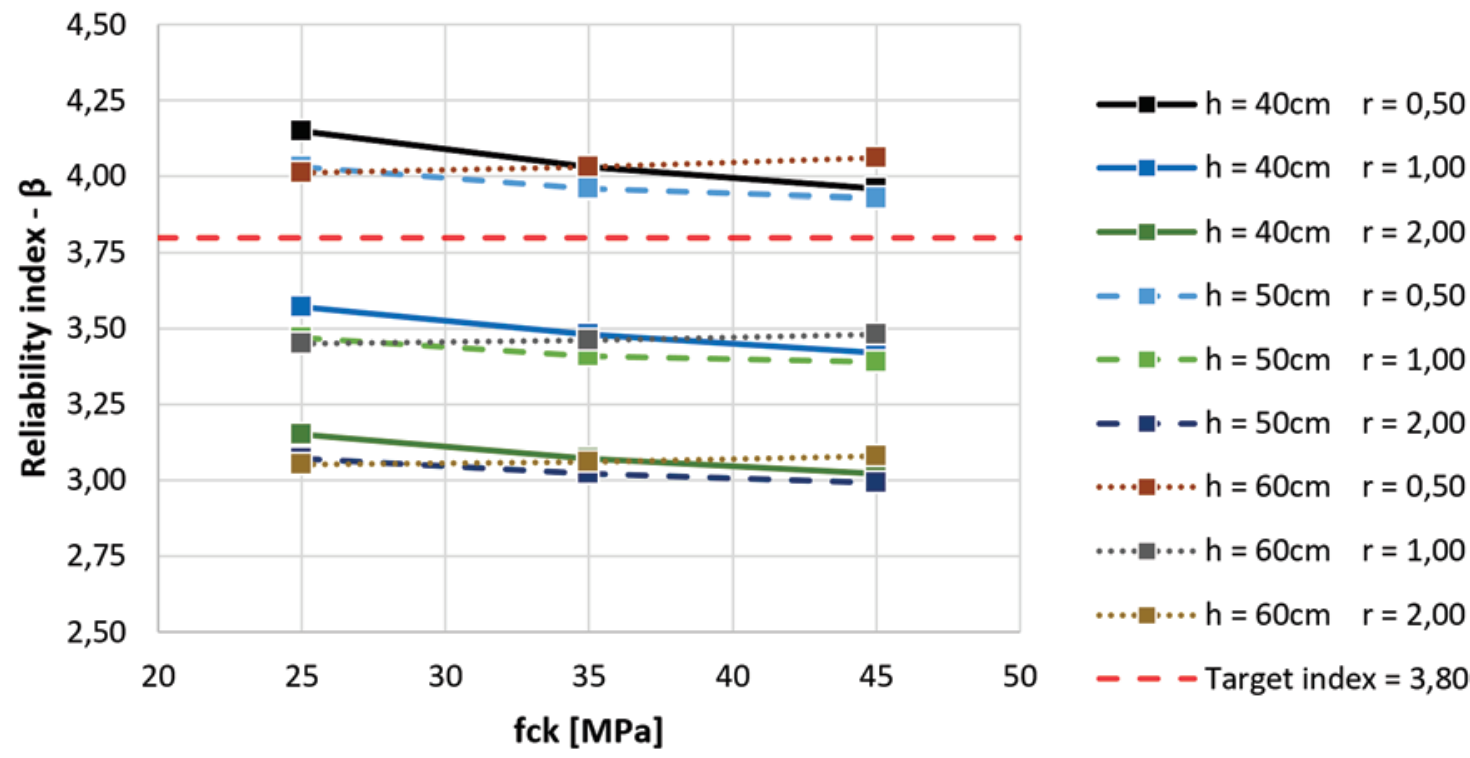

Figure 7.2

Variation of the reliability index as a function of fck $(p k=20 \mathrm{kN} / \mathrm{m})$ 
fib 2010 model code is considered, which is $\beta_{\text {target }}=3.80$ for reinforced concrete structures.

Figures 7.1 to 7.3 show the variation of the reliability index versus the characteristic strength variation of the concrete for beams subjected to a characteristic load of $15 \mathrm{kN} / \mathrm{m}, 20 \mathrm{kN} / \mathrm{m}$ and $25 \mathrm{kN} / \mathrm{m}$, respectively, under different combinations of section heights and load ratios. It is observed a subtle tendency of reduction of the reliability index as a function of the increase of the characteristic strength of the concrete. For beams with higher cross-section height and/or higher characteristic strengths, however, a tendency of increase in the reliability index was observed, justified by a small increase in the average resistence of these beams as a function of the tensioned concrete's contribution. This behavior is most evident in beams with a lower total characteristic load, such as those shown in Figures 7.1 and 7.2.

It is also observed that, for different cross-sectional heights, the reliability indexes tend to present a good uniformity. The load ratio, in turn, tends to significantly change the reliability index, leading to a reduction of this as the live load becomes predominant in the load combination. Finally, it can be observed that the increase in the value of the total characteristic load does not promote appreciable changes in the reliability indexes.
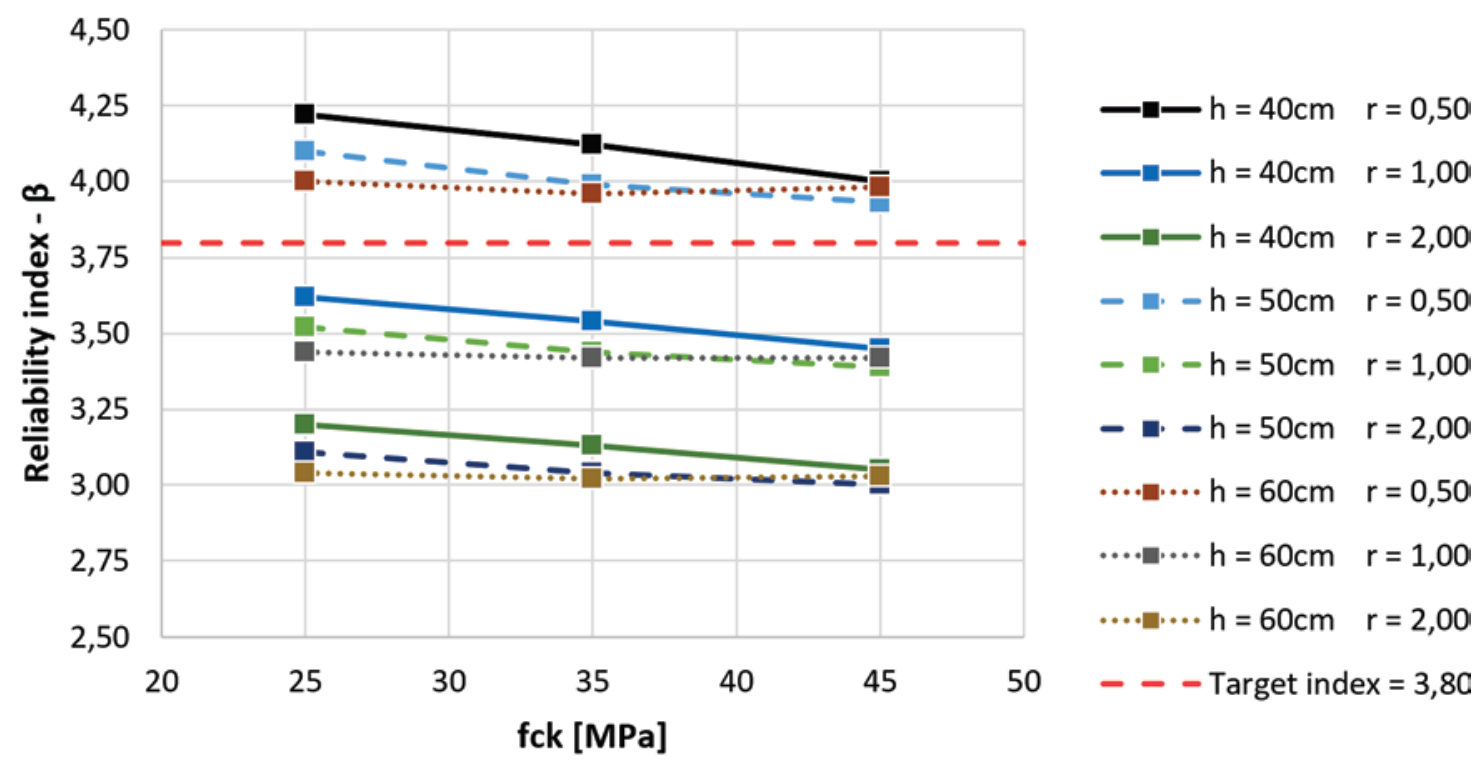

Figure 7.3

Variation of the reliability index as a function of fck $(p k=25 \mathrm{kN} / \mathrm{m})$

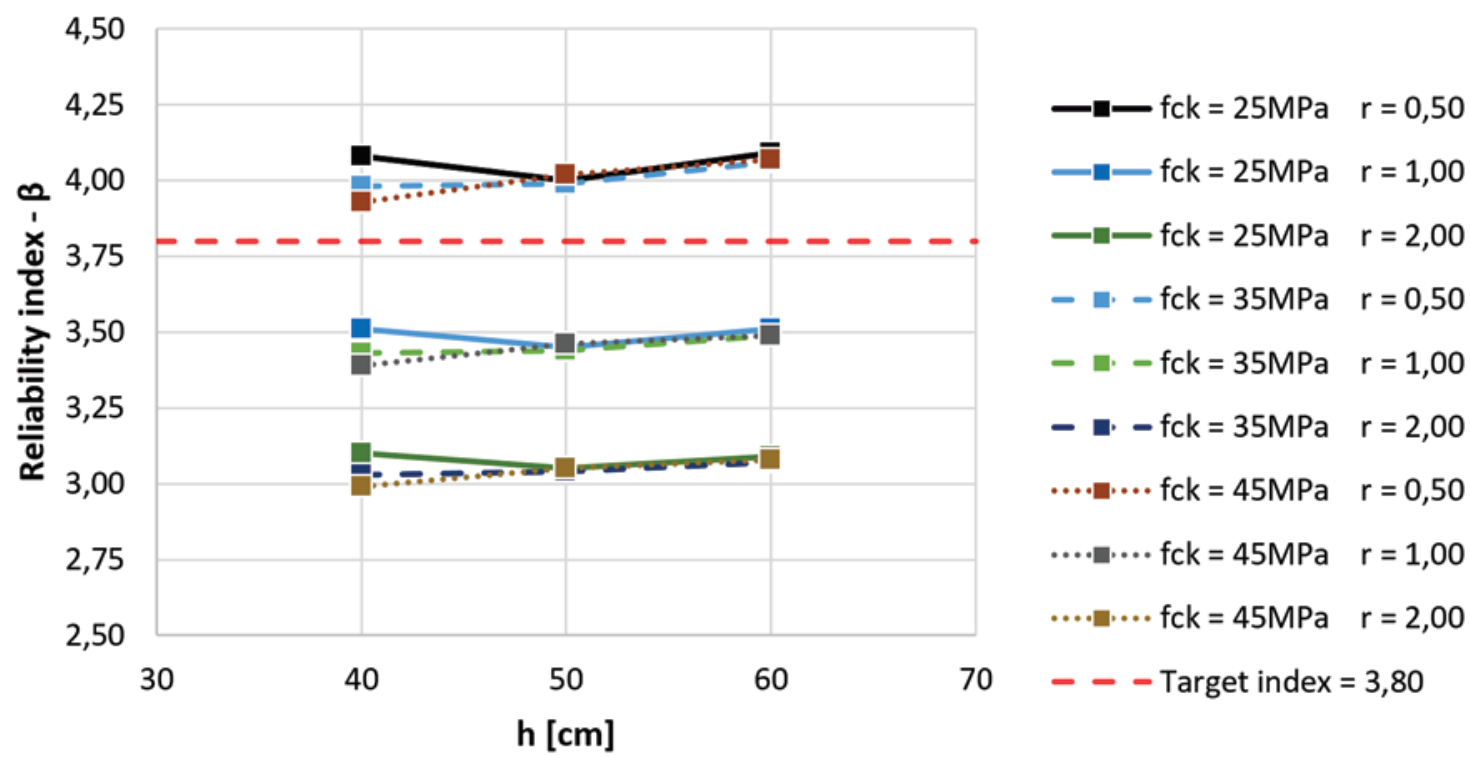

Figure 7.4

Variation of the reliability index as a function of $h(p k=15 \mathrm{kN} / \mathrm{m})$ 


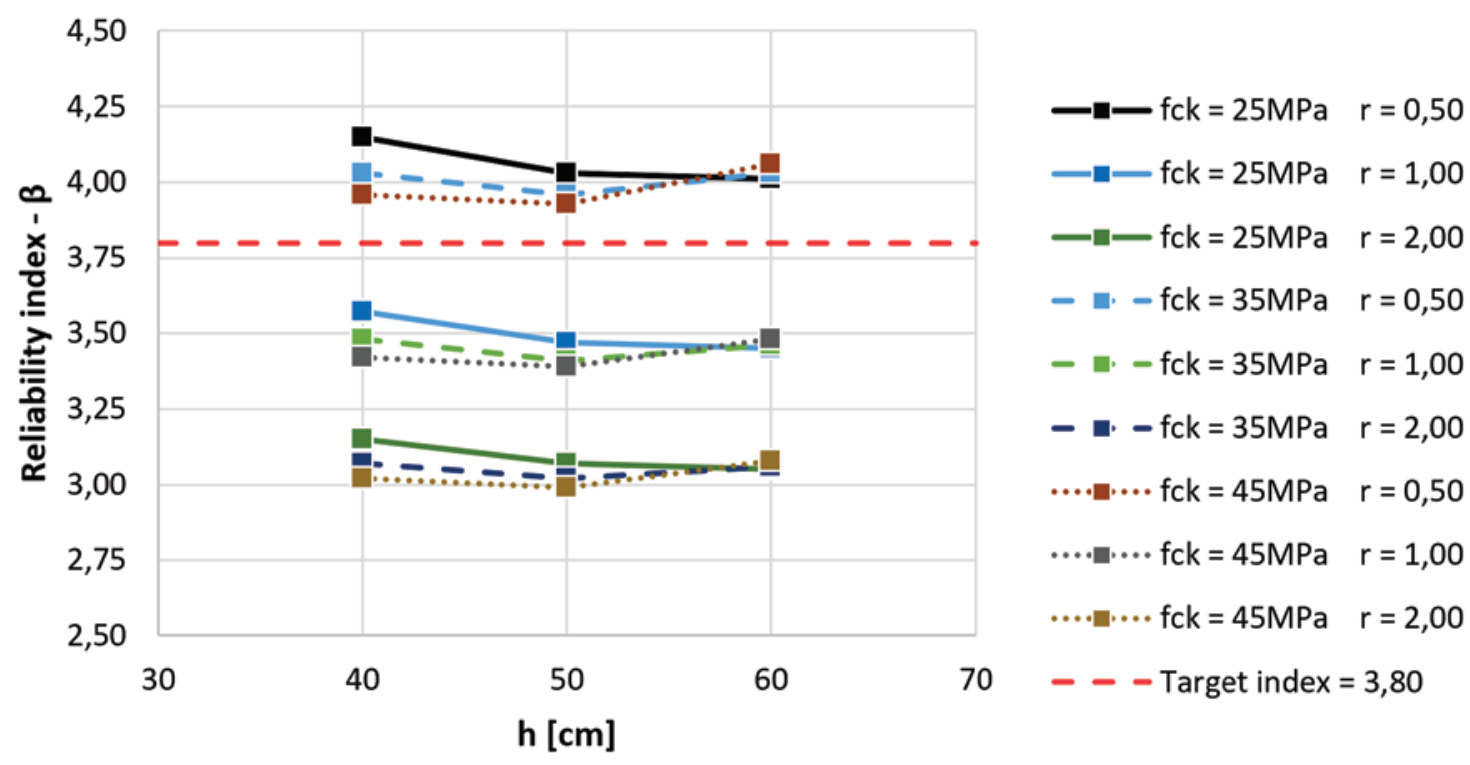

Figure 7.5

Variation of the reliability index as a function of $h(p k=20 \mathrm{kN} / \mathrm{m})$

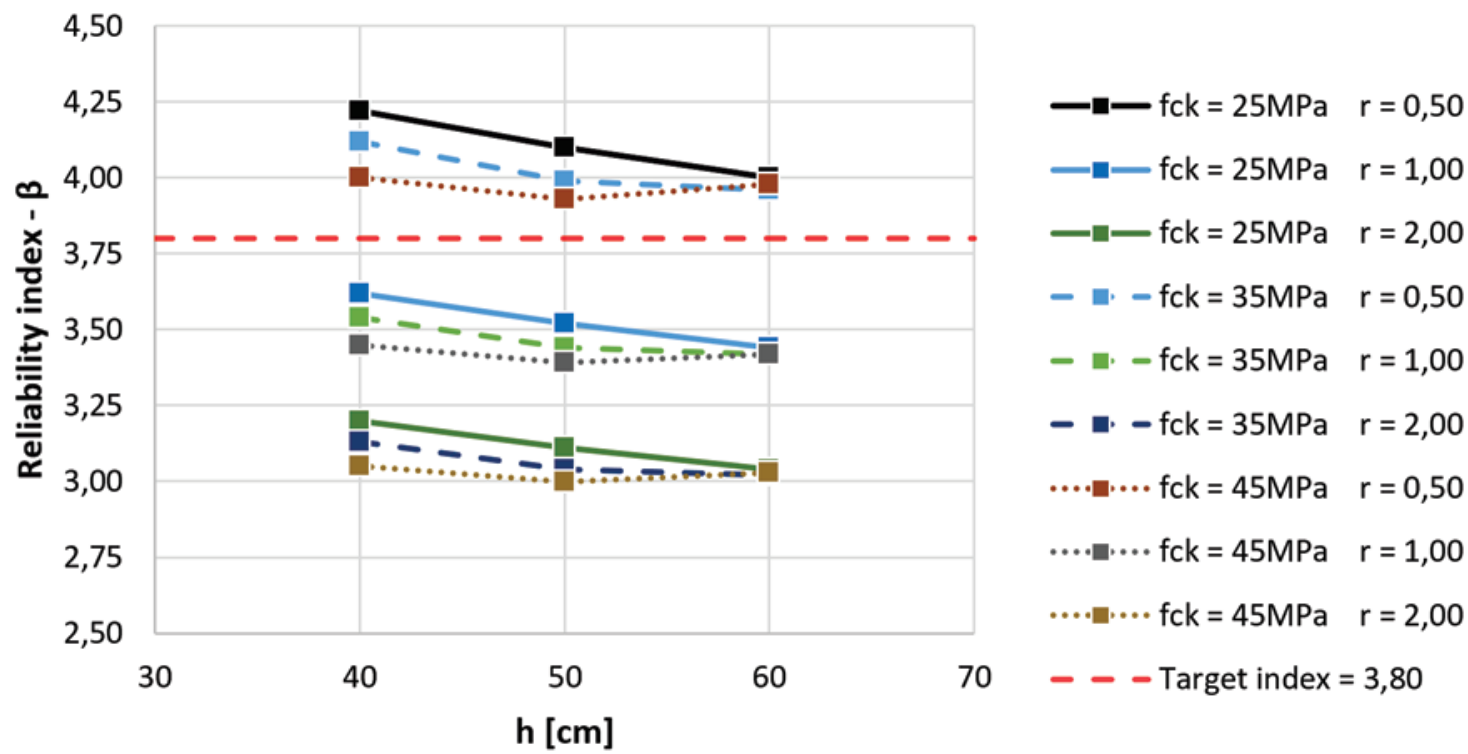

Figure 7.6

Variation of the reliability index as a function of $h(p k=25 \mathrm{kN} / \mathrm{m})$

Figures 7.4 to 7.6 show the variation of the reliability index versus the cross-sectional height variation for beams subjected to a characteristic load of $15 \mathrm{kN} / \mathrm{m}, 20 \mathrm{kN} / \mathrm{m}$ and $25 \mathrm{kN} / \mathrm{m}$, respectively, under different combinations of characteristic strengths of concrete and load ratios. It is observed that the contribution of the tensioned concrete to the beams with a lower total characteristic load tends to manifest with the increase of the height of the cross section, even for the lower values of characteristic stength of the concrete, inducing a small increase in the average of the resistance and, therefore, subtly increasing the reliability indexes. This condition can be seen more clearly in Figure 7.4. For beams with a higher total load characteristic, however, it is observed that the increase of the height of the cross section leads to a small reduction of the reliability indexes. The loading relationship was shown to be a factor of greater influence on the reliability index, reducing them in a recurrent way for the loading ratios $r=1.0$ and $r=2.0$.

\section{Conclusions}

The present study evaluated the safety level achieved by a set of 
81 beams in relation to the ultimate limit state of flexure. The beams were designed according to the requirements of NBR-6118:2014 code, which governs the procedure of designing concrete structures in Brazil. This set of beams contemplated combinations of different concrete properties, cross section heights, load combinations and different total characteristic load values.

The Finite Element Method and the Monte Carlo Method were used to obtain the main statistical parameters of the resistence of the studied beams. The random variables included in the simulations are presented in Table 6.1. From the data obtained through simulation, a normal probability distribution was set for the representation of the resistance of each of the 81 beams. The reliability indexes of this study were obtained by FORM, considering the performance function given by the expression (6.1). In addition to the variable corresponding to resistance, obtained through simulation, the performance function was composed by the variables arranged in Table 6.2.

Through the parametric study, it is observed that the reliability indexes of the studied beams presented few changes due to variations in the characteristic strength of the concrete. Subtly higher reliability values associated with lower characteristic strengths can be observed, which can be attributed to the higher reinforcement ratio of these beams. Minasi [16], in his study, also verified that the isolated variation of this parameter does not significantly modify the levels of reliability obtained. In the present work, it was also verified that the variation in the height of the cross-section does not promote appreciable changes in the reliability indexes.

With respect to the resistence of the beams, a small increase in the ultimate resistence of the beams was observed, for geometric configurations and mechanical properties of the materials that lead to an increase in the contribution of the tensioned concrete, resulting in a small increase in the reliability indexes for beams with a lower total characteristic load.

Regarding the value of the total characteristic load, this study showed a low influence on the reliability values achieved. This same trend was observed in Santos et al. [12]. In contrast, a great influence of the load ratio $r$ is observed, with the reliability index showing considerable reductions when live load becomes predominant in the load combination. This behavior was also observed in Santos et al. [12] and Minasi [16]. This variation is justified by the large coefficient of variation attributed to the live portion of the load. Of the 81 beams evaluated, a total of 54 presented reliability indexes lower than the stipulated target index. All indexes that resulted below the target index correspond to load combinations in which the live load is proportionally equal to or greater than the dead load, which indicates that the current weighting coefficients for accidental loads do not guarantee a uniformity in reliability indexes for cases where live loads become preponderant in the load combinations.

It should be noted that the reliability indexes obtained in this research are results of approximations, from those associated with the mechanical behavior of the materials, to those related to the attribution of theoretical distributions for each random variable. Adding to this is the unidimensionalization of the resistance variable, which is represented by a random variable $\mathrm{R}$ with normal probability distribution. A more precise result is expected using the Response Surface Method, where $\mathbf{g}(\mathbf{X})$, a function of the finite ele- ment model, is now represented by an approximation polynomial, adaptively constructed at the project point inter- mediations [24] . Another alternative is the direct coupling of reliability subroutines with the finite element program. In this approach, the function $g(X)$ is treated implicitly, the components $\partial \mathrm{g} / \partial \mathrm{X}_{\mathrm{i}}^{\prime}$ of the gradient being computed numerically [23,24].

Finally, considering the approach carried out in this work, it was verified that the different distributions tested for resistance $\mathrm{R}$ did not reflect in large variations in the reliability indexes obtained. These results can be justified by the directional cosines of the random variables (Figure 6.9). It is possible to note that for the performance function adopted, corresponding to the ultimate limit state of flexure, the influence of $R$ is not preponderant in relation to the other variables. This fact ratifies the adopted approaches and qualifies the results obtained.

\section{Acknowledgements}

The authors would like to acknowledge the financial support of CAPES and CNPq.

\section{References}

[1] REAL, M. V. Análise Probabilística de Estruturas de Concreto Armado, Sob Estado Plano de Tensão, Através do Método dos Elementos Finitos. 2000. 249 f. Tese (Doutorado em Engenharia Civil) - PPGEC, Universidade Federal do Rio Grande do Sul, Porto Alegre.

[2] AGRAWAL, G.; BHATTACHARYA, B. Partial safety fator design of rectangular partilly prestressed concrete beam in ultimate flexural limit state. Journal of Structural Engineering. [s.I]. v. 37. n. 4. p. 257-267. 2010.

[3] ARAÚJO, J. M. Curso de Concreto Armado. 4 vols. Rio Grande: Editora Dunas, 2014.

[4] ASSOCIAÇÃO BRASILEIRA DE NORMAS TÉCNICAS. NBR 6118: Projeto de estruturas de concreto - Procedimento. Rio de Janeiro, 2014.

[5] BARBOSA, P. R. Análise probabilística de pilares de concreto armado através do método dos elementos finitos. 2017. 198 f. Dissertação (Mestrado em Engenharia Civil) - PPGEC, Universidade Federal do Rio Grande do Sul, Porto Alegre.

[6] ANSYS, Inc. ANSYS Mechanical APDL Element Reference. Release 15.0, 2013

[7] HINTON, E. Numerical methods and software for dynamic analysis of plates and shells. Swansea: Pineridge Press, 1988.

[8] SHEGG, A.; DECANINI, L. Sobre las deformaciones em elementos de hormigón armado, In: Jornadas Sulamericanas de Engenharia Estrutural. Porto Alegre, Brasil. Anais, v. 2, p. 1071-1120. 1971.

[9] NOWAK, A. S.; COLLINS, K. R. Reliability of Structures. McGraw-Hill Companies, Inc., 2000

[10] HALDAR, A.; MAHADEVAN, S. Probability, Reliability, and Statistical Methods in Engineering Design. JohnWiley \& Sons, New York, 2000.

[11] SILVA, G. R. Análise da confiabilidade da ligação laje-pilar interno sob punção de acordo com a NBR-6118:2014. 2017. 174 f. Dissertação (Mestrado em Engenharia Civil) - PPGEC, Universidade Federal do Rio Grande do Sul, Porto Alegre. 
[12] SANTOS, D. M.; STUCCHI, F.R.; BECK, A.T. Confiabilidade de vigas projetadas de acordo com as normas brasileiras. Revista Ibracon de Estruturas e Materiais. São Paulo. v. 7. n. 5. p. 723-746. 2014.

[13] GALAMBOS, T. V.; ELLINGWOOD, B.; MACGREGOR, J. G.; CORNELL, C. A. Probability based load criteria: Assessment of current design practice. Journal of the Structural Division, v. 108. p. 959-977. 1982.

[14] COMITÉ EURO-INTERNATIONAL DU BÉTON. CEB-FIB Model Code 2010. Lausanne, Bulletin n. 65, 2012.

[15] MARTINELLI, M. Modelagem de situações de punção em lajes de concreto armado através do método dos elementos finitos. 2003. 149 f. Dissertação (Mestrado Engenharia Civil) - PPGEC, Universidade Federal do Rio Grande do Sul, Porto Alegre.

[16] MINASI, A. T. Confiabilidade de vigas de concreto armado em estruturas portuárias no estado limite último de flexão. 2016. 149 f. Dissertação (Mestrado Engenharia Oceânica) PPGEO, Universidade Federal do Rio Grande, Rio Grande.

[17] SZERSZEN, M. M; NOWAK, A. S. Calibration of Design Code for Buildings (ACI 318): Part 2 - Reliability Analysis and Resistance Factors. ACI Structural Journal, v. 100. n. 3. p. 383-391. 2003.

[18] DINIZ, S. M. C; FRANGOPOL, D. M. Reliability Assessment of High-Strength Concrete Columns. Journal of Engineering Mechanics, v. 124. n. 5. p. 529-536. 1998.

[19] SZERSZEN, M. M; SZWED, A; NOWAK, A. S. Reliability Analysis for Eccentrically Loaded Columns. ACI Structural Journal, v. 102. n. 5. p. 676-688. 2005.

[20] FERREIRA, L. M; NOWAK, A. S; EL DEBS, M. K. Desenvolvimento de equações para a limitação do peso de veículos de carga em pontes de concreto através da teoria de confiabilidade. Revista Ibracon de Estruturas e Materiais. São Paulo. v. 1. n. 4. p. 421-450. 2008.

[21] MAGALHÃES, F. C; REAL, M. V; SILVA FILHO, L. C. P. The problem of non-compliant concrete and its influence on the reliability of reinforced concrete columns. Material and Structures, v. 49. n. 4. p. 1485-1497. 2016.

[22] ANG, A. H-S.; TANG, W. H. Probability Concepts In Engineering. John Wiley \& Sons, Inc., 2007.

[23] BECK, A. T.; ROSA, E. Structural reliability analysis using deterministic finite element programs. Latin American Journal of Solids and Structures, v. 3. n. 3. p. 197-222. 2006.

[24] LEONEL, E. D.; BECK, A. T.; VENTURINI, W. S. On the performance of response surface and direct coupling approaches in solution of random crack propagation problems. Structural Safety, v. 33. n. 4. p. 261-274. 2011. 